\title{
A LONGA HISTÓRIA DA CULTURA JURÍDICA MEDIEVAL
}

\author{
THE LONG HISTORY OF THE MEDIEVAL LEGAL CULTURE
}

José Reinaldo de Lima Lopes*

\begin{abstract}
"O cientista dever ordenar: a ciência se faz com fatos, como uma casa se faz com pedras; mas um punhado de fatos é tão pouco ciência quanto um amontoado de pedras é uma casa. Portanto, os fatos brutos não bastam. Por isso se faz necessária a ciência ordenada e generalizada. Dizse frequentemente que é necessário fazer experiência sem idéias preconcebidas. Isso não é possivel: não somente isso equivale a tornar estéril qualquer experiência, mas mesmo que se quisesse não seria possivel. Todos levam em si a própria concepção de mundo da qual não se podem desfazer facilmente".
\end{abstract}

(CALASSO, Francesco. Elogio della polemica. In:

Storicita del diritto. Milano: Giuffrè, 1966. p. 99).

\begin{abstract}
Resumo:
$\mathrm{O}$ texto traça um panorama do direito medieval destacando seu caráter erudito e filosofante, o qual determina que os juristas sejam atores públicos importantes naquele período, usem o método filosófico com certa desenvoltura, e façam uso de gêneros literários definidos. O texto aponta para a diferença da experiência inglesa e termina referindo ao humanismo jurídico, escola que expressamente rejeita parte da tradição medieval.

Palavras-chave: Direito medieval. História do direito. Cultura jurídica medieval. Humanismo jurídico. Comentadores. Glosadores.
\end{abstract}

\begin{abstract}
:
This paper presents a panoramic view of Medieval law, stressing its scholarly and philosophical character, which defines lawyers as important public characters at the time, imposes them the use of the philosophical methods and definite literary genres. The text points out the difference of the English experiment and eventually mentions legal humanism, the school of thought which clearly rejects part of the medieval tradition.
\end{abstract}

Keywords: Medieval law. Legal history. Medieval legal culture. Legal humanism. Commentators. Glossators.

* Professor Titular da Faculdade de Direito da Universidade de São Paulo. 
Pequeno afresco daqueles tempos

Era o outono de 1494 quando Carlos VIII, rei de França, entrava em Florença. Naqueles dias, quando o sol começava a fugir do céu do Mediterrâneo e a respiração do Atlântico trazia a chuva sobre a Europa meridional, também o brilho do renascimento italiano começava esmaecer. Era o início do outono da idade mais brilhante da república do Arno. O quatrocento havia sido seu século nas coisas do espírito e da carne; o cinquecento, depois de uma sangrenta provação, seria o século de Roma, como disse belamente Jean Delumeau. Florença deixava esvair pouco a pouco também o que havia sido o humanismo na Itália. O humanismo jurídico teria seu epicentro em França, cujos reis, a partir de Carlos VIII justamente, se haviam imiscuído nos assuntos dos Estados italianos. Naquele ano de 1494 não só Florença era invadida por Carlos VIII: frei Savonarola, possuído da fúria dos reformadores, instalado no belo convento de São Marcos - em cujas paredes estavam as suaves pinturas do beato frade João de Fiesole (1387-1455), o Fra Angélico - promovia não só reforma política como também regulava as vidas dos cidadãos em nome da limpeza dos costumes e da restauração da vida republicana. Savonarola abriu as portas da cidade para Carlos VIII, com quem mantivera tratativas quando o rei se encontrava na vizinha cidade de Pisa. A intervenção de Carlos VIII levou a guerra ao território da Itália e por cinquenta anos a península tornou-se o palco da luta entre França e Espanha, uma tentando tomar posse de Nápoles e do sul da Itália em nome da antiga herança da casa de Anjou, os angevinos, a outra fazendo valer a conquista dos aragoneses. Os Estados italianos se dividiam na disputa, ainda acirrada anos mais tarde quando o imperador do Sacro Império, que formalmente detinha o norte da Itália, tornou-se rei de Espanha (Carlos I de Espanha e V da Alemanha, 1500-1558). Roma foi invadida e saqueada em 1527 pelas tropas do Imperador. A cristandade, que já se chocara com a revolução e a Reforma alemãs, deflagradas pela liderança espiritual e nacional de Lutero e Melanchton, estarreceu-se com o saque da Cidade Eterna.

A visão que se poderia ter do mundo naqueles anos era nada menos que apocalíptica. Não é por acaso que tantas representações da morte e do fim do mundo surgiam em toda parte. Não é por acaso também que Dürer (1471-1528), importante personagem das artes plásticas na Alemanha, e Miguelangelo (1475-1564), o gênio italiano, tenham celebrizado em seu tempo as representações do dia do juízo, o dia da ira (dies irae) de Deus sobre o mundo de um modo totalmente diferente daquele usado por Frei Angélico décadas antes. Nada mais contrastante com essas quinhentistas e dramáticas representações do fim dos tempos do que as obras do beato frade. Embora seu desenho e espontaneidade sejam já pós-medievais, o sentido de ordem, harmonia e liturgia de seu Juízo Final (no Museu de São Marcos, em Florença) podem ser como uma representação da hierarquia que Etienne Gilson vislumbrou na obra de Tomás de Aquino, na célebre 
metáfora em que compara a Suma Teológica a uma catedral gótica: cheia de ordem, de colunas de sustentação, de arcos que ligam as abóbadas, elevando-se sempre mais e simultaneamente mantendo a harmonia do conjunto. Se o juízo final de Miguelangelo, ou o de Dürer, é atormentado e dramático, o do Frei Angélico é uma festa, que une Céu e Terra, é a celebração da harmonia final entre o divino e o humano, é uma liturgia em andamento. É esperançoso e otimista. Essa imagem mostra a ruptura de mentalidade que há entre a Idade Média e a Modernidade. Embora se mantenha muito do mundo medieval, mesmo algumas de suas bases materiais (suas fontes de energia só mudarão radicalmente no século XVIII - com o vapor - e no século XIX - com a eletricidade e os motores de combustão interna), processa-se alguma mudança. Dessa forma, é de se suspeitar que também na esfera da cultura jurídica, muito, ou alguma coisa pelo menos tenha mudado.

Neste texto procura-se dar uma visão de conjunto e introdutória da cultura jurídica medieval, mais especificamente da Baixa Idade Média, concentrando-me na experiência do direito erudito das universidades. Se considerarmos que esse direito abarca três ou quatro séculos, desde o século XI (o estabelecimento do Studium de Bolonha e a Querela das Investiduras como seus marcos iniciais) até o século XVI (humanismo jurídico, reforma protestante, afirmação do conceito moderno de soberania e declínio das universidades) é fácil perceber que há e pode haver muitas divisões. Se acrescentarmos a esses séculos os outros dois em que o direito erudito ainda se mantém fortemente assemelhado ao ius commune, isto é, os séculos XVII e XVIII, nos quais além da língua latina, sobrevivem entre os juristas os textos romanos e o hábito da formação casuística - só a custo suplantado pelo direito natural racionalista e sistemático moderno -, é ainda mais evidente o quanto de diferenças deve haver entre os juristas e as escolas abrigadas sob o nome geral de 'direito medieval' ou 'direito comum'. Sucedem-se distintos problemas teóricos e práticos a serem resolvidos, de modo que todo tratamento panorâmico, sintético e unitário pecará por muita simplificação.

Não é demais lembrar alguns fatos: o efeito demograficamente catastrófico da peste negra em 1348. Alguns cálculos mostram um decréscimo populacional estimado em cerca de 20 milhões de pessoas entre 1300 e 1350 (cf. ROMANO; TENENTI, 1977, p. 7). Também a Igreja latina sofreu significativos reveses: o chamado exílio de Avinhão, entre 1309 e 1377, quando o papado instalou-se no território francês e se colocou em uma posição politicamente subalterna aos interesses do rei de França, enquanto tentava recuperar-se de uma crise financeira anterior; o cisma do Ocidente, entre 1378 e 1417 quando se apresentavam dois ou até três papas em oposição, até que o Concílio de Constança conseguisse pôr fim à divisão. Nessa altura, a própria ideia de centralização monárquica do papado viu-se abalada pela força política e intelectual do conciliarismo, particularmente ativo na Universidade de Paris (TIERNEY, 1968). 
Começo por uma pequena história da universidade medieval e pela inserção do estudo do direito (canônico e civil) nos cursos superiores. Apesar de a Idade Média ser uma civilização diferente da nossa, o fato de o direito tornar-se, a partir do século $\mathrm{XI}$, objeto de ensino universitário é determinante para a experiência histórica ocidental (SCHIAVONE, 2005). Em seguida, acompanhando uma sugestão de Marc Bloch, de que a história do direito poderia bem ser a história dos juristas (BLOCH, 1990, p. 116), mostro como eles eram membros de uma corporação que se tornou particularmente relevante na vida urbana, e se aproximaram das instâncias de poder. Na terceira seção exploro o método empregado pela jurisprudência medieval no ensino, e menciono brevemente a questão da autonomia do direito, cuja consciência foi tão importante para legistas e canonistas. Uma quarta seção dá conta sumária dos gêneros literários e a quinta detémse sobre algumas doutrinas jurídicas, buscando mostrar a complexidade do período em termos de pensamento dogmático. A sexta parte refere-se à experiência inglesa, original, mas, ainda assim, parte da "civilização jurídica ocidental". Concluo com uma referência ao humanismo jurídico, que pelo método e construções dogmáticas pôs fim ao mundo medieval, ainda que não ao 'ius commune'. Como diz sinteticamente Bellomo, o 'ius commune', constituiu o 'passado comum da Europa' entre 1100 e 1800 (BELLOMO, 1994, p. xi). Mesmo que se estabeleça a cesura entre direito medieval e moderno no século XVI (com o humanismo), no século XVII (com o jusnaturalismo), ou no século XVIII (com o direito nacional e o iluminismo), até o advento do Estado nacional burguês podese falar de certa comunalidade.

$\mathrm{O}$ 'direito comum' europeu afirma-se na universidade, quando se introduz o ensino dos livros legais, ou seja, do direito romano redescoberto, ou revivido, na Itália setentrional. Por longa sucessão de eventos, a Itália do Norte, que havia passado a Carlos Magno, viera a pertencer ao Império Romano 'renovado', dos Otões. Com Oto I coroado em 962, e Oto II, seu filho, que tomou o título de Imperador em 982, a ideia e as frágeis estruturas de um império romano pareciam restauradas. Escapavam ao controle do Imperador e sempre foram limites a sua pretensão universal - isto é, de domínio da cristandade latina - os reinos da França, ducados e condados mais tarde incorporados ao reino francês, a Península Ibérica e as Ilhas Britânicas. Na Itália, garantia-se autonomia aos Estados Pontifícios. O direito romano redescoberto parecia naturalmente o direito do império restaurado. Dentro daquele território, as cidades (comunas) e repúblicas se desenvolveram e sobreviveram. Gênova, Pisa, Amalfi, Veneza eram repúblicas mercantis com grande riqueza e contato com o Oriente. A redescoberta do direito romano e seu estudo erudito transcenderam, contudo, as fronteiras da Itália e do Império, e foram a pouco e pouco se expandindo nas zonas da Europa que também reivindicavam a herança latina, e se submetiam ao patriarcado do bispo de Roma (antes que ao patriarcado de Constantinopla, a Nova Roma). 
Outra fonte do direito comum, o direito canônico, afirma-se na mesma época e também depende do estudo universitário. Era comum por ser o direito da Igreja de obediência e rito latino, essencialmente romano. Esse braço do direito comum - o direito canônico - foi de importância extraordinária. Os trabalhos de Brian Tierney (1968 e 1997) e de Walter Ullmann (1946 e 1968) mostram como no seu âmbito foram elaborados conceitos fundamentais, inclusive o de direito subjetivo, o de pessoa jurídica (corporação, corpus mysticum), o de superioridade dos conselhos sobre os papas (teoria conciliarista), o de ordem do processo, e muitos outros. A elaboração do direito canônico fez-se dentro de duas tensões estruturantes segundo Tierney (1968, p. 1): (a) entre regnum e sacerdotium, e (b) entre uma versão monárquica e absoluta, e uma versão conciliar e corporativa do poder interno da Igreja.

O nascimento das universidades

O surgimento da universidade tem um ambiente próprio. Ela é uma corporação entre outras corporações, dentro da renovação econômica e social instalada no século XI e cuja geografia coincidirá com a geografia do renascimento do comércio no interior do continente. Corporação significa corpo: a universidade é um dos corpos do corpo maior, o corpo político, seja a comuna ou cidade, seja o reino ou império. A dinâmica da riqueza mobiliária do comércio, ainda que subalterna à riqueza da terra, cria uma espécie de rota de 'transumância' mercantil e de peregrinos que vai da Flandres à Itália. Estabelece-se essa rota, a rigor, entre muitas fronteiras simbólicas e políticas: no sentido longitudinal na fronteira Leste-Oeste entre as terras do Sacro-Império e o reino da França, e no sentido latitudinal na fronteira Norte-Sul entre o Sacro-Império e os Estados pontifícios. Grossi (1968, p. 135) resume o lugar e o momento da origem das universidades com a tríade 'cidade, escola, tráfico'.

As duas primeiras e mais importantes universidades surgem respectivamente (1) em Paris, no reino de França, dominando sobre a filosofia e a teologia, e (2) em Bolonha, na própria fronteira entre os territórios pertencentes ao papa e o Império, reinando no direito. As duas universidades, ou studia, têm organizações e origens bem diferentes. Primeira no tempo, segundo uma legenda ainda corrente, Bolonha nasce de forma totalmente nova, como uma corporação de estudantes e "laica", distante do bispo, da catedral, da escola diocesana. Sua origem estava provavelmente num studium talvez patrocinado pela própria comuna de Bolonha. Paris, ao contrário, é uma universidade de professores e nasce à sombra da catedral parisiense. Enquanto Paris ficou conhecida como uma 'universitas doctorum' (corporação de doutores), Bolonha identificou-se com uma 'universitas scholarium' (corporação de estudantes). Analisando os estatutos disponíveis para a primitiva universidade bolonhesa, Savigny chega à conclusão de que devem ter 
sido os estudantes a primeiro se organizarem em corporação (universitas), como qualquer outro grupo profissional usava à época (SAVIGNY, 1854, p. 553-557). Embora Paris se houvesse consagrado como centro de filosofia, foi no campo da teologia que seu nome se firmou como universidade. Bolonha, ao contrário, transformou-se em sinônimo de direito (civil e canônico), e Salerno identificou-se com a medicina.

A data de constituição de cada uma das universidades nem sempre é bem conhecida. Várias delas, suspeita-se, tiveram origem em experiências de ensino anteriores, sem que houvesse um estatuto ou constituição a definir-lhes a existência. Ainda se debate como e quando exatamente surgiu a universidade de Bolonha. Em Paris, como se sabe, a universidade desdobra-se, desenvolve-se, da escola diocesana, da escola da catedral. Já não é a escola do mosteiro (rural), mas da diocese (urbana) e dela procede a nova organização dos estudos (VERGER, 1999).

O caso de Bolonha é menos claro e para o direito é o mais interessante. A despeito de não se poder datar com precisão o início, há um consenso, e já o havia na Baixa Idade Média, de que Bolonha era o berço do estudo do direito. Em 1155, quando Frederico Barba-Ruiva foi à Itália receber a coroa, passou por Bolonha, reuniu-se com os mestres e estudantes e publicou, sob a forma de uma constituição imperial, os Authentica habita, reconhecendo-lhes alguns privilégios. Pode-se datar daí o mais antigo 'estatuto’ da universidade medieval, indicando que já estavam em atividade os professores de leis de Bolonha. De fato, algumas décadas antes o legendário Irnério (c. 1050-1130?), segundo testemunha Odofredo (SANTINI, 1990, p. 232) já era professor de artes liberais, quando começou a ler os livros jurídicos, os Libri legales. Sabe-se que Pepo teria lecionado em Bolonha ainda antes, entre 1070-1100; Irnério o fez entre 1112 e 1125 . Deve ter havido escolas privadas de direito, mas em 1155 o Imperador Frederico I, Barba-Ruiva, como já foi dito, concedeu os privilégios aos estudantes configurando definitivamente uma universitas, ou seja, uma corporação (pessoa jurídica) autônoma em jurisdição e capacidade de autorregramento. Em outras passagens do mesmo Odofredo (sempre segundo Santini) há referências ao fato de Irnério ter sido lógico, isto é, professor de lógica. Dessa forma, não é de estranhar que desde o começo o direito estivesse associado ao método dialético, desenvolvido exemplarmente por Pedro Abelardo (1079-1142).

Supõem alguns que a origem do estudo do direito tem fundamentos bem práticos. Nesse caso, o studium de Bolonha não teria surgido apenas pelo desejo de sofisticação ou pelo exercício puro e simples de esforço filosófico analítico, ou mesmo pelo divertissement de gente desocupada. Por esta linha de pesquisa e interpretação, associa-se Bolonha a uma escola destinada a aperfeiçoar os notários. Notários eram personagens importantes, pois ajudavam as partes a dar forma escrita a seus negócios e foram frequentíssimos na Itália medieval. Para o direito mercantil tiveram importância ao redigir os contratos e documentos dos comerciantes, preparando as minutas discutidas 
pelas partes, além de lhes dar a publicidade e o registro; na vida das cidades tiveram também grande relevância pois consta que auxiliavam da mesma maneira os representantes das comunas (BERMAN, 1983, p. 355 e 392). De fato, o mesmo Savigny conta que os notários formavam colégios próprios nas cidades e organizavam sua pertença. Costumavam mesmo 'ler' os textos de direito romano, de modo que 'pode ter ocorrido que sua escola fosse vista como um apêndice daquela dos juristas' (SAVIGNY, 1854, p. 734). ${ }^{1}$

$O$ certo é que a universidade era um corpo a mais nas cidades, a começar por Bolonha, no caso da faculdade de direito, e que nela houve sem dúvida uma precedência dos alunos. Ao longo do tempo a precedência dos alunos cedeu à crescente importância dos professores, que passaram então a deter a função de reitores, isto é, autoridades com jurisdição sobre o corpo discente. Para se ter uma ideia da importância de uma corporação como essa na cidade, basta dizer que em 1150 Bolonha teria cerca de dez mil estudantes na sua população (BERMAN, 1983, p. 160). Números expressivos também havia em Paris, de modo que a grève, isto é a secessão de uma corporação dessas, afetava a própria vida da cidade (perda de clientes de livreiros, copistas, locadores, estalajadeiros etc.).

Paris, cuja origem deitava raízes no estudo da filosofia e da teologia teve estatutos confirmados pelo papa, não pelo Imperador, em 1215. A vida de estudos provavelmente os precedera de alguns anos. Durante o século XIII surgiram ainda outras universidades em França: Orleãs, Toulouse e Montpellier. Na Inglaterra foram estabelecidas Oxford (1214) e Cambridge. Outros estúdios (studia) apareceram em outras cidades do norte da Itália: 1215 em Arezzo, 1222 em Pádua. Na mesma Itália vale mencionar ainda a universidade de Siena (1246) e, ao Sul, a universidade de Nápoles (1224), criada por Frederico II. Na Espanha considera-se que Afonso IX de Leão tenha fundado Salamanca (privilégios concedidos em 1254), mas talvez já houvesse um studium em Palencia (1180?), ainda que pouco se saiba da sua relevância para o direito (MARTÍNEZ DÍEZ, 1980, p. 257). Em Portugal o studium generale foi criado por D. Dinis, em 1288, em Lisboa, com a concordância do papa, transferido anos mais tarde para Coimbra.

No século XIV criaram-se universidades em Avinhão e Roma (1303), Perúgia (1308), Grenoble (1339), Praga (1347), Florença (1349), Pavia (1361), Viena (1365). Como se vê, só na segunda metade do século XIV, cerca de duzentos anos depois da bem-sucedida experiência bolonhesa, apareceram universidades no âmbito de língua alemã do Império. Praga, na Boêmia, foi a primeira, e durante algum tempo (até 1417), a mais importante delas, recebendo, por isso, um maior número de estudantes da Europa oriental e setentrional, que Moraw (1996) chama de Europa nova, pois de cristianização recente (por volta do ano 1000).

Sobre os notários ver, sobretudo, Ennio Cortese (1999, v. 2, p. 64-68). 
Intelectuais e juristas do poder?

A civilização medieval foi uma civilização jurídica, e a Baixa Idade Média foi em muitos aspectos uma civilização do direito culto. Os juristas colaboraram sempre na regulamentação da vida política das monarquias feudais, das comunas (repúblicas), dos próprios feudos. Em meio ao chamado 'renascimento do século XI' (HASKINS, 1955) começava a pouco e pouco o desenvolvimento do novo grupo social, os intelectuais, os homens de saber, que já não exclusivamente homens da Igreja. Começava uma vida intelectual dissociada da clausura dos mosteiros ou das catedrais. Esse novo tipo afirmouse devagar, lutando para ter reconhecido o seu direito de ensinar mediante remuneração e, finalmente, para viver deste saber si, da manipulação dos conceitos e das relações de pensamento (LE GOFF, 2003, passim). Naturalmente o jurista será um dos tipos mais interessantes desse novo quadro. A especificidade desse novo tipo de jurista, formado na e formador da universidade, está no fato de vir a constituir em toda parte um grupo social com identidade e, portanto, estatuto próprio. Na Inglaterra, cuja história difere da história do continente, os candidatos a juristas 'profissionais' juntavam-se em torno dos inns of court, os pátios interiores dos tribunais régios, para ali formarem uma escola ou guilda em que os aprendizes dedicavam-se a imitar a arte, o ofício, dos mestres - juízes e oficiais da justiça. Na Europa continental a corporação em que se formavam era a universidade (universitas, corporação). Também ali o aprendizado consistia na imitação domínio da arte ou ofício de seus mestres. Esta arte, a dialética, operava sobre um objeto específico, o corpo do direito romano.

Em ambos os casos, Inglaterra e Europa continental, delineia-se uma relação social durável. Os juristas ingleses associam-se diretamente ao poder régio. Sua educação é voltada para fornecer ao rei os oficiais necessários a sua corte. Relação análoga aparece no continente: sua associação com os tribunais régios também ocorrerá e será intensa. Tão intensa que na primeira metade do século XIX Tocqueville poderá dizer com segurança e serenidade:

Há quinhentos anos que os juristas tomam parte em todos os movimentos da sociedade política européia. Algumas vezes foram instrumentos das autoridades políticas, outras vezes fizeram daquelas autoridades instrumentos seus. (...) Sempre que os nobres quiseram que os advogados dividissem com eles alguns de seus privilégios, as duas classes encontraram muitas coisas que facilitaram seu acordo e, por assim dizer, concluíram que pertencem à mesma família. (TOCQUEVILLE, 1988).

O que foram socialmente os juristas medievais no continente? Sua inserção social deu-lhes o privilégio, ou seja, o monopólio do ensino do direito. A licentia docendi, 
ou os títulos universitários, representavam uma carta patente para operar intelectualmente o direito. Claro que nada disso significava que a vida jurídica cotidiana dependesse dos juristas. O direito medieval vivo continha em si hábitos, costumes, tradições, fontes de obrigação que em grande parte independiam das universidades, especialmente no 'direito privado’, como diz Paolo Grossi. A sociedade medieval não era uma sociedade burocrática, não era a Alemanha guilhermina do século XIX. E, no entanto, os juristas construíram seu caminho na política e na alta política. Como e por que fizeram isto?

Em primeiro lugar, ainda quando não formados exclusivamente como quadros burocráticos, estavam presentes e ajudaram a formar o grande movimento de expansão das comunas e da vida política dos séculos XIII a XV. Dentro dele espalharam nas escolas de direito a semente, tirada do direito romano, da racionalização do poder. Eram chamados a desempenhar duas tarefas, com cada vez maior frequência. Primeiro tornaram-se conselheiros de príncipes e de particulares. Tomem-se as obras de Bártolo de Sassoferrato (1313-1357), uma espécie de jurista medieval por antonomásia: suas famosas questões, opiniões e conselhos deixaram-nos um repertório de pareceres dados a pedido de variadas pessoas, de comunas a herdeiros privados de grandes ou médias fortunas. Quase tudo e quase todos os personagens da vida medieval podem ser vistos sob a pena de Bártolo. Por que? Certamente porque se valorizava crescentemente uma opinião douta, e porque as questões entre todos esses personagens se poderiam resolver em instâncias formais, como as cortes, cúrias, tribunais e árbitros. Segundo, ao serem chamados a integrar os tribunais, para lá levaram sua maneira de decidir as questões. Em um mundo em que a lei escrita, feita pelo arbítrio do príncipe, era apenas uma parte das regras a aplicar, podiam, quando em posições de poder, nelas introduzir seus hábitos, seus raciocínios, sua forma de argumentar, e as autoridades que lhes pareciam adequadas para solucionar os casos, a cultura jurídica letrada e erudita, sua interpretatio enfim.

Sua intimidade com o poder nota-se muito cedo. Os 'quatro doutores', Búlgaro, Hugo, Jacobo, Martino, uma geração seguinte à de Irnério, estiveram todos a serviço do Imperador e aparecem inúmeras vezes na Glosa Ordinária, editada por Acúrsio (1189-1259), em 1250: Búlgaro é citado cerca de 315 vezes, Martino cerca de 590, Jacobo 30 vezes. Búlgaro (?-1166) ajudou a produzir o texto confirmando os direitos régios (regalia) do Imperador Frederico Barba-Ruiva em 1158 na Dieta de Roncália. Jacobo colaborou nas dietas do Império e foi também juiz em Bolonha. Rogério advogou em processo famoso sobre direitos feudais da Provença no tribunal de Turim, defendendo Hugo de Baux contra o Conde de Barcelona. Alderico serviu na corte episcopal de Bolonha e Módena (LANGE, 1997, p. 164-190). Piacentino (+ 1192), exilado em Montpellier, retornou a Bolonha onde, a pedido e na casa da família Castello ensinou direito. Sua ida a Montpellier deveu-se, segundo alguns (CALASSO, 1959, p. 86-87) a razões políticas, dado seu envolvimento na disputa entre a comuna e o Imperador. Odofredo e Acúrsio 
foram assessores do Podestá de Pádua e Bolonha respectivamente. Bártolo combinava sua posição de jurista e professor com a de ativo cidadão de Perúgia. Em maio de 1355 o jurista integrou a missão perugina que defendeu os interesses da comuna junto ao Imperador Carlos IV (QUAGLIONI, 1983, p. 67). Baldo, seu discípulo e sucessor, teve cargos públicos na mesma Perúgia e igualmente foi convocado a participar de missões diplomáticas: em 1370, junto ao papa Urbano V, e em 1381, junto a Carlos III de Durazzo (CANNING, 2003, p. 7).

Moraw (1996) mostra que o número de membros do alto clero (bispos) que frequentaram a universidade foi crescente na França medieval. No reinado de Luís VIII (1137-1180) apenas 3\% dos bispos haviam estudado nas escolas superiores, número que saltou para 41\% cem anos depois no reinado de Luís IX (1226-1270). Na Cúria de Avinhão havia 66 cardeais formados na universidade, dos quais $71 \%$ detinham o título em direito. Entre 1280 e 1320 contavam-se 189 juristas letrados a serviço do rei de França: 131 como juízes e 58 como advogados. Visto que os adversários do rei também contratavam juristas para opinar e defendê-los perante os tribunais, o número de juristas envolvidos nos tribunais régios era certamente maior (MORAW, 1996, p. 255). Durante a curta vida da escola de direito da Universidade de Praga (1347-1417) houve também expressivo número de juristas (3.563), apesar de consideravelmente menor dos que se achavam na Europa ocidental e meridional. De toda sorte, em Praga, primeira escola no território alemão, estudava-se a jurisprudência como 'ciência da elite' (MORAW, 1996, p. 260). Na Espanha, já no final da Idade Média, calcula-se que 11,7\% dos cargos mais altos da administração de Isabel, a Católica, e Fernando de Aragão fossem ocupados por letrados.

Em Portugal D. Dinis (1261-1325) encareceu ao papa Nicolau IV o estabelecimento do studium de Lisboa para facilitar o curso de decretos (direito canônico) e leis (direito romano justinianeu). A universidade foi criada por volta de 1288-1290 e lentamente a cultura do direito erudito penetrou no reino. Em 1385 um jurista aparece com papel político preeminente: o doutor João das Regras, que estudara em Bolonha em 1378 (CAETANO, 1996, p. 452-455). João das Regras não havia sido eleito por ninguém (por nenhum dos 'corpos' ou 'estados') para as cortes de Coimbra na qual se discutia a sucessão do trono, mas figurava como membro do Conselho do rei. Sua presença e a atividade são indicativas da posição dos juristas cultos nos círculos de poder. Marcelo Caetano dá também notícia da lei de D. Afonso IV, de 1352, em que se estabeleceu o limite da aplicação do direito romano - e por isso mesmo testemunha sua influência.

A história da formação do direito erudito, universitário, é na Europa meridional e ocidental um caso de longa e progressiva maturação. Tratava-se de zonas de romanização forte, interrompida durante séculos, mas nas quais a volta dos textos romanos não era vista como uma importação abrupta ou totalmente exógena. De fato, Odofredo dizia nos seus Comentários ao Digesto (Comm. Dig. 1.1.16), sem precisão histórica, que 
os textos romanos haviam sido levados para Ravena e de lá haviam sido transportados para Bolonha (libri legales fuerunt deportati ad civitatem Ravenne et de Ravenna ad civitatem ista [Bolonha]). Geograficamente era plausível a ideia, pois Ravena, a capital bizantina da Itália no século V d.C., era um porto de mar na foz da planície padana e Bolonha, por seu turno, era a primeira grande cidade nas primeiras encostas dos Apeninos para quem da planície do Pó procurava galgar as montanhas para chegar, por terra, à Toscana (Etrúria) e depois ao Lácio (Roma). A Gália antiga (Sul da França), assim como a parte cristianizada da Ibéria haviam conhecido o direito vulgar dos romanos na forma do Código de Alarico, ou Lei romana dos visigodos.

Uma coisa era a romanização antiga, interrompida havia mais de cinco séculos, outra era a onda erudita. Esta se espalhou com o ensino universitário, dentro do qual o direito romano aparecia ou como direito vigente (na medida em que o império havia sido transferido para a Baixa Idade Média seja pelo imperador mesmo, seja pelo que o papa herdara da Roma imperial - traslatio imperii), ou como instrumento de racionalização do direito local (funcionando nesse caso como ratio scripta). Nessa condição (ratio scripta) influiu, por exemplo, nas Siete Partidas, mandadas compilar por Afonso X, de Castela (c. 1263). As Partidas não chegaram a ser promulgadas pelo Rei Sábio, mas foram confirmadas em 1348, junto com os Ordenamientos de Alcalá de Henares. A cronologia é significativa: o texto deve ter ficado pronto treze anos após a Grande Glosa de Acúrsio (1250), e enquanto não valia propriamente como lei, servia como instrumento de racionalização aberto a quantos aplicavam o direito castelhano ou local, servindo-lhe finalmente de base para a unificação progressiva (SÁNCHEZ-ARCILLA BERNAL, 2004). Assim o direito erudito ajudava a modificar os costumes locais.

Não foi preciso que acontecesse, na maioria desses países da Europa Meridional o que houve na Europa setentrional: ali, em 1495, na tentativa de dar alguma unidade ao império, Maximiliano I instituiu um tribunal geral de última instância (Reichskammergericht) que deveria usar o direito romano (ius commune) (CAENEGEM, 1991). Por isso nos territórios de língua alemã fala-se tanto de uma 'recepção', com tanta e tal força: é que ali o direito romano encontrou um solo menos tradicional onde instalarse, pois não era tão fácil fazer referência a uma tradição romana anterior. Na Europa do Norte, aquela nova Europa de Moraw, a entrada do direito romano foi feita por cima, pelos juristas.

O estudo do direito: filosofia, análise e escolástica

A universidade e o ensino universitário do direito são elementos determinantes da cultura jurídica tardo-medieval, ainda que se possa sempre fazer a ressalva de que estamos aqui tratando da alta cultura, da cultura de um grupo social que 
detém riqueza e poder, e mais riqueza e mais poder do que as grandes massas. Este ensino desenrolava-se sob algumas formas mentais e pressupunha alguma cultura cuja existência terminou por unificar o discurso dos juristas na Europa. Por isso mesmo chamou-se a esse direito doutrinal, erudito, acadêmico, de direito comum, o ius commune, cujas fronteiras eram, por assim dizer, a cristandade latina, nas respectivas repúblicas, reinos, principados..., no próprio império.

No final do século VIII e início do século IX o esforço de Carlos Magno e de Alcuíno de Iorque [York] (730-804) havia restabelecido algum ensino sistemático. Alcuíno fora chamado de Iorque, de onde bebera nas fontes de Elberto, o sucessor de Beda, o Venerável. A pedido de Carlos Magno transferiu-se para a França e foi a alma do renascimento carolíngeo. Estimulou o ensino do trivium e do quadrivium, mas, dizem alguns que os dois séculos seguintes (IX e X) não conseguiram fazer frutificar o legado de Alcuíno a sua altura. O papel de Alcuíno foi, contudo, significativo e começouse até mesmo a falar de uma traslatio studiorum a Paris: dizia-se que a França, mais particularmente Paris, havia recebido a universidade que houvera em Atenas e Roma antigas.

O método usado pelos juristas derivava da filosofia apresentada sob a forma da lógica. A lógica medieval teve extraordinária importância. Foi até objeto de certa 'confusão' com a metafísica, isto é, a filosofia das coisas primeiras. O período que antecedeu imediatamente o florescimento da escola dos glosadores, o século IX, a primeira escola jurídica universitária por assim dizer, foi dominado pela controvérsia dos dialéticos, os filósofos, com os teólogos. Em termos simplistas: a dialética pretenderia dispensar a teologia (tudo pode ser investigado pela razão, cujo artefato essencial é a lógica), enquanto a teologia poderia dispensar a dialética, já que tudo procederia da sabedoria divina. Representaram os dialéticos Anselmo de Beaste e Berengário de Tours; representou os antidialéticos Pedro Damião. Desta polêmica surgiram, finalmente, os pensadores capazes de aceitar a filosofia e fazê-la conviver com a tradição, abrindo espaço, no século XI, ao renascimento intelectual: Anselmo de Cantuária (1033-1091) e, na geração seguinte, o celebre Pedro Abelardo (1079-1142). Esses intelectuais não ignoravam a tradição que lhes chegara da Antiguidade e na qual se valorizava a obra de Cícero, em geral, e a de Boécio, os dois que haviam transmitido algo da lógica antiga e de suas partes (a tópica, a retórica, a dialética, a hermenêutica). Abelardo tornou-se o professor de filosofia por excelência, e desenvolveu o método e os temas sobre os quais vieram a trabalhar os medievais durante tanto tempo. Abelardo ensinava seus alunos, na Lógica para principiantes (Logica ingredientibus), como ela seria o instrumento para toda filosofia e para todo pensamento. A ordem adequada de apresentação da disciplina estava na sequência (para ele 'lógica') dos termos simples, das proposições e das argumentações. Assim, poder-se-ia acompanhar no ensino, com muito proveito, as obras de Aristóteles 
(as Categorias, para os termos, o Peri Hermeneias, para as proposições, e os Tópicos e Analíticos para os argumentos). A Lógica para principiantes tinha a intenção justamente de "instruir o leitor nas Categorias de Aristóteles". (ABELARDO, 1994, p. 35).

Assim como a lógica exigia distinções, o direito poderia ser compreendido sob distinções. "Onde encontrares uma contradição, faz uma distinção" era o lema de análise escolástica (herdeira do Sic et non de Abelardo). O estudo do direito era estudo superior, ao qual só tinham acesso alunos que passassem pelas artes liberais. Estas, opostas às artes mecânicas, compunham-se de dois grupos: as disciplinas do pensamento e do uso do discurso ou palavra, as artes sermonicales (artes da língua), e aquelas cujo objeto eram as coisas mesmas, as artes reales. As sermonicales abrangiam as três disciplinas daí seu nome trivium: gramática (arte da correção), a lógica (arte dos argumentos sobre o necessário) e a retórica (arte dos argumentos sobre o meramente possível). As reales compunham-se de quatro disciplinas - daí seu nome quadrivium: aritmética, geometria, astronomia e harmonia. Com essa formação iam os estudantes debruçar-se sobre os textos de direito, romano ou canônico.

Esse método tornava os juristas rigorosos, pois evitava o uso indiscriminado das palavras. A aplicação das distinções era corriqueira e habitual. A título de exemplo, veja-se o caso de Azo (?-1220), professor de Acúrsio (1185-1263): inicia seus comentários ao Código (Suma Azonis super libros codicem) com uma distinção, evitando o uso ambíguo dos termos. Comentando o Livro II do Código (Codex, II, De Edendo) começa criticando os que identificavam ação e direito: na linguagem comum pode-se significar que ter ação e ter direito são a mesma coisa, mas direito propriamente é aquilo que se exige, diz ele. É preciso, portanto, distinguir, assumindo como pressuposto para qualquer trabalho a distinctio. O jurista medieval cria uma 'afinadíssima instrumentação lógica e uma linguagem conceitualmente rigorosa' (GROSSI, 1968, p. 140). Os romanistas (legistas) debruçavam-se sobre o direito romano e de lá tiravam suas definições (distinções), especialmente das Instituições de Justiniano e do Digesto. Em toda parte as distinções: Bártolo, o jurista por antonomásia, abordava os temas iniciando sempre pelas muitas formas de uso dos termos. "Multas deffinitiones iustitiae habemus in glosa" (temos muitas definições de justiça na Glosa), ou "Videamus primo quae est differentia inter publica et communia” (vejamos primeiro qual a diferença entre o 'público' e o 'comum') (Super Institutionum commentaria). De outra parte, procurava a diferença entre usus, mos, consuetudo. E a palavra cidadão, a que se referia? Ao habitante, ao natural, a qualquer um (cf. Consilia, LXII)? Será que as diferentes palavras referiam-se a diferentes realidades? A distinção bem feita evitava erros de raciocínio e a armadilha de tomar a palavra em um sentido (impróprio) e não no outro (próprio). Se os conceitos estivessem embaralhados debaixo da mesma palavra, o raciocínio tornar-se-ia inconclusivo, por violar o primeiro princípio de toda lógica, o princípio da identidade. De fato, Piacentino dizia: “Quando 
magis res omnis distinguetur, tanto melius operatur" (quanto mais se distinguem as coisas, melhor se age). É claro que as distinções poderiam converter-se em simples sutileza da linguagem, e poderiam multiplicar-se sem fim: esse desvio perigoso das distinções foi, passados alguns séculos, o responsável pela conversão da escolástica em um jogo vazio, um exercício 'flamejante' de vocabulário. Mas no início não era disso que se tratava.

Graciano já fizera isto para o direito canônico (c. 1140). Sua obra fundadora organizava-se em torno das distinções. O que eram elas? Distinções conceituais: sob a mesma palavra poderiam ocultar-se duas ou mais ideias diferentes. A Concórdia dos cânones discordantes - mais tarde conhecida simplesmente como o Decreto de Graciano (Decretum Gratiani) - iniciava exatamente pela lista de usos que se faziam das palavras lex e ius. Distinguia depois os direitos (leis) divino e humano, repartia o direito humano em secular e eclesiástico e prosseguia com essas Distinções por cerca de uma centena de trechos (seções), as chamadas 101 Distinções.

Como eram as relações entre juristas, teólogos e filósofos? Nem sempre foram das melhores. Há o famoso texto da Glosa de Acúrsio (1250), segundo o qual a verdadeira sabedoria (filosofia?) encontrava-se no saber civil (direito): "vera sapientia in civilis sapientia". Irnério mesmo, lucerna iuris para os glosadores, foi criticado mais tarde por Bassianus por ser excessivamente filosófico, tendo feito glosas "mais obscuras que o próprio texto da lei", enquanto Piacentino e Azo diziam que se deveria mesmo esquecer a dialética (apud LANGE, 1997, p. 116-117). Pedro Bellapertica (+1308), professor em Orleãs, repreendia seus alunos, que vinham do estudo de filosofia em Paris e desprezavam o saber jurídico. Tudo isso refletia, segundo Lange, a consciência por parte dos juristas da autonomia de sua disciplina, em relação à filosofia e à teologia. Mas, adverte o próprio Lange na mesma passagem, não se deve exagerar o distanciamento, nem esquecer que os juristas não formavam um bloco monolítico, e embora nem todos os glosadores tivessem frequentado as artes liberais, tinham de qualquer maneira um estudo anterior e compartilhavam, querendo ou não, o espírito da época e da ciência da época (1997, ibidem).

É nesse último sentido a afirmação de Calasso (1959, p. 333), segundo a qual havia uma 'osmose de método, técnica, forma literária entre direito, filosofia e teologia', ainda que houvesse também a consciência da própria autonomia. O direito medieval, entretanto, segundo sua opinião expressa no mesmo trecho, não era tão impregnado da filosofia quanto veio a ser o direito moderno, particularmente o direito natural moderno que, a seu juízo, foi uma tentativa mais explícita de submeter os princípios do direito aos mesmos princípios da filosofia cartesiana e da ciência demonstrativa. ${ }^{2}$

Um discípulo de Calasso, contudo, nos apresenta um estudo demonstrativo da importância da filosofia, ou se quisermos da teoria propriamente dita no pensamento jurídico medieval: Ennio Cortese (1962, v. 1, p. 
Piano Mortari insiste no fato de os métodos da filosofia, particularmente da lógica, terem sido de importância fundamental para os medievais. "O caráter científico da jurisprudência era fundado, para os Comentadores, de um lado na eternidade, necessidade e imutabilidade dos princípios jusnaturalistas - dos quais derivavam as normas positivas -, de outro da possibilidade de os juristas elaborarem a matéria jurídica por meio dos instrumentos da dialética: 'rectus modus theoricae procedendi est triplex, s. diffinitivus, divisivus, et exemplorum positivus'. ${ }^{3} \mathrm{O}$ uso das formas lógicas de argumentar foi ainda considerado de extrema importância pelos juristas medievais, tanto quanto pelos teólogos, no desenvolvimento de sua atividade interpretativa". (PIANO MORTARI, 1976, p. 207).

O latim continuava a ser língua universal dos eruditos, de modo que não eram necessárias traduções dos textos romanos. Mas nos séculos XI, XII ou XIII era preciso contar com as novas línguas vernáculas, nas quais se desenrolava a vida de todos os dias. Nelas, insinuaram-se novos termos: directum, além do tradicional ius, convivia com constitutio, mores, cânon, statuta, habita, rescripta. Formas variadas, fontes variadas. Os termos eruditos foram fixados em textos não exclusivamente dos juristas romanos: havia uma enorme produção de literatura cristã (dos padres latinos: Ambrósio, Agostinho, Jerônimo, Gregório), dos concílios, de Isidoro de Sevilha. Não era só, e talvez não fosse principalmente, a literatura clássica que fazia uso dos termos. E as instituições romanas haviam desaparecido, dando lugar a outras muito diferentes. Tudo isso levava ao desenvolvimento e à necessidade das muitas técnicas interpretativas, quase como 'traduções'. Assim, a interpretatio dos medievais exigia certa proximidade com a dialética, e pressupunha a unidade de sentido do Corpus Iuris, já que Justiniano mesmo mandara expurgar da coletânea as normas incoerentes. Os juristas diziam de que as palavras eram signos contingentes do sentido permanente que se deveria pressupor nos textos (a ratio legis, ou a mens legis). Esse sentido deveria ser coerente (afastar-se de contradições com outras normas) e equitativo (preservar a justiça e a equidade, finalidades últimas do direito) (PIANO MORTARI, 1972, p. 277). A interpretação deveria, pois, coordenar sistematicamente as várias normas, começando pelas normas do próprio Corpus Iuris Civilis, chegando depois à sistematização de todo o direito positivo, isto é, do direito comum, dos direitos locais, dos privilégios, etc. (PIANO MORTARI, 1972, p. 279). ${ }^{4}$

A doutrina medieval era por isso mesmo chamada interpretatio: tratava-se de aplicação do saber sobre um conjunto de textos vindos da tradição. A impressão falsa que se deve evitar é a de que a doutrina medieval fosse assistemática e irracional. Tratava-

143-296), nos três capítulos dedicados ao tema da causa.

3 "O modo correto de proceder teoricamente é triplo: definindo, dividindo, pondo exemplos".

4 Cf. também Brian Tierney (1963, p. 378-400), onde se demonstra que o conhecimento integral do Corpus Iuris transformava sua interpretação numa interpretação de um todo, logo, de um corpo coerente. 
se de uma forma de sistematização, mas não analítico-dedutiva. A noção que hoje se tem do sistema jurídico - forjada ao longo dos séculos XVIII e XIX - é influenciada pela idéia chave de dedução analítica: todas as normas, até a norma mais específica que determina uma ação concreta, deve estar implicada em uma norma superior e mais geral. Assim, todo o trabalho jurídico consistiria em ex-plicar uma norma que está im-plicada na norma superior. O que unifica tudo é uma vontade superior (o Legislador) de onde tudo procede. Nossa maneira de conceber o conjunto das normas pressupõe que as normas mesmas procedem umas das outras. No caso do direito medieval o sistema não é tanto dependente da vontade de ninguém, mas da 'natureza' das coisas (forma, finalidade, estrutura), e toda a interpretação está orientada (adquire sentido) para o equânime. Assim, a solução dos casos e das contradições entre as normas passa pelo que Mortari expõe: (1) uma interpretação literal (pois o texto existe realmente e as palavras com as quais é feito precisam ser levadas a sério), (2) uma interpretação lógica ou sistemática (pois o corpo de direito, romano ou canônico, é um todo integrado e sensato, com sentido - um corpus, não um amontoado de palavras), e (3) uma interpretação finalística (pois é insensata um nonsense - a interpretação que resulte em soluções absurdas do ponto de vista da justiça ou da equidade). Esse era o saber dos medievais, isto é, controlado não apenas pelo 'procedimento', mas pelo 'resultado'. Tinha-se em mente, na interpretação sistemática e finalística, que o direito não poderia ser aplicado (e interpretado) de modo a prejudicar aquilo ou aqueles cujo propósito era justamente beneficiar. O texto de Modestino conservado no Digesto (D. I, 3, 25) servia de exemplo para a interpretação conforme a finalidade da lei: "Nenhuma razão de direito ou benignidade da eqüidade admite que nós, por meio de uma interpretação mais dura, conduzamos aquelas coisas que salutarmente se introduzem pela utilidade dos homens a uma severidade contra a vantagem deles próprios". Havia de fato um princípio exegético nos medievais consistente em pôr em relação umas com as outras as normas recolhidas no corpo do direito justinianeu por meio da interpretação sistemática dos conceitos e regras ali encontrados (PIANO MORTARI 1976, p. 95). Havia uma busca de coerência, na linha avançada pelo próprio Justiniano ao promulgar as Pandectas, segundo a qual não se deveriam encontrar contradições no texto e caso parecessem existir deveriam ser integradas e solucionadas.

A falta de sistema e de poder político estatal concentrado precisa ser compreendida nesse contexto. A ordem jurídica medieval não pode, não quer e não formula uma noção de Estado (no sentido contemporâneo) e menos ainda de Estado de Direito, mas, como diz Quaglioni (2004a, 24), pode-se quase falar de um 'estado de justiça'. Quaglioni cita a expressão de Bártolo, ao comentar o Codex $(1,22,6)$ : “O príncipe não poderia fazer uma lei sequer que contivesse algo desonesto ou injusto. Isto contradiria a própria substância da lei que é definida como aquela santa sanção que ordena as coisas honestas e proíbe as coisas contrárias (D. 1, 3, 2)". 
Esse sentido da ordem jurídica é dado pela noção de justiça, não só pela noção de procedimento válido, ainda que, como se verá adiante, a noção de procedimento válido e formalmente organizado não fosse estranha a canonistas e legistas.

Com tudo isso, pode-se ter uma ideia do papel que a dialética, uma das 'artes' ensinadas pelos filósofos, desempenhou no pensamento jurídico. Ao lado da autonomia que se formava, e dependia de 'categorias' tipicamente jurídicas, dava-se o recurso aos artefatos intelectuais proporcionados pelas 'artes'. O resultado, porém, não foi uma nova filosofia, mas uma disciplina especial, uma interpretação doutrinal que sobre o material romano criava a partir da consciência moral submetida à exigência histórica (GROSSI, 1968, p. 139).

O ensino, ainda que baseado nos textos, era também casuístico, dilemático e problemático. Desenvolvia-se com o artefato intelectual da filosofia: a quaestio, a questão. A habilidade a ser desenvolvida pelo estudante, para vir a tornar-se um mestre em leis, era resolver questões e contradições. As contradições poderiam estar entre as próprias regras, ou seja, nos textos mesmos. Para saber se os textos eram ou não potencialmente contraditórios era preciso em primeiro lugar conhecer o texto completo (o Corpus Iuris), já que o sentido está no todo, não nas partes. Por isso, como já se fazia com a Sagrada Escritura, o mestre precisava ler integralmente o material cuja unidade se pressupunha.

Exigia-se, pois, uma extensa leitura (lectio), um curso de lectiones. Como condição prévia da boa leitura, seria necessário que se estabelecesse a correção do texto: era preciso conferir o texto, e esta fase chamava-se justamente conferentia. Lição (leitura) e conferência eram instrumentais, preliminares ao que realmente interessava: utilizar o texto para resolver questões. A questão poderia referir-se tanto a uma contradição (contrarietatis) de um texto com outro texto, quanto a uma dúvida sobre o resultado de sua aplicação no caso concreto (dubitatio). Havia que saber aplicar a regra escolhendo a melhor para o caso, tanto para não cair na ignorância de outra que excepcionasse a aplicação da primeira (dispensatio, exceptio), ${ }^{5}$ quanto para não cair na solução absurda, injusta, irracional, inaceitável, impossível faticamente ou impossível logicamente (que não se poderia justificar).

Não é difícil ver como as primeiras gerações de juristas - e aqui vale tanto para os canonistas quanto para os civilistas (legistas) - tiveram como tarefa mais importante determinar o sentido dos textos, trabalho foi de glosa e de organização. Nada mais exemplar do que a obra de Graciano, já precedida por tentativas anteriores. Sua primeira tarefa era consolidar no material recolhido (os cânones), mais tarde conhecido como Decretum, o Decreto de Graciano, tudo o que de geral poderia ser encontrado em

Sobre o uso da equidade para a dispensa ou exceção cf. Lawrence Joseph Riley (2012). 
termos de disciplina da Igreja. Não era uma compilação de dogmas ou artigos de fé, mas de regras que sancionavam os fiéis (clérigos ou leigos) quando da prática pública de sua religião. Havia produção imensa de normas de concílios gerais e locais, de decisões dos papas que resolviam dúvidas e arbitravam conflitos carecendo de integração. Como fazer isto? Em primeiro lugar reunindo tudo em um só corpo, um só texto. Em segundo lugar explicando os termos. Por isso o trabalho de Graciano foi composto - como já se disse - de uma primeira parte chamada 'Distinções' e uma segunda parte chamada 'Casos'. Na primeira ele confronta várias normas para sugerir que diziam respeito a um mesmo objeto e que poderiam ser lidas juntas, embora fosse necessário 'distinguir' as variações e extensões dos respectivos significados (por exemplo, seus 'âmbitos de validade'). Na segunda parte aplicava, em casos controversos, as regras que lhe pareciam indicadas.

Com um curso de estudos de natureza semelhante - dominado pela habilidade de aplicar normas a casos e tomando como base um texto estabelecido pela tradição, o corpus iuris civil ou canônico - era possível formar juristas para todos os lugares da cristandade em que houvesse memória e respeito pelo direito romano. Foi assim que puderam constituir-se em uma classe simultaneamente 'cosmopolita' e operativa nos tribunais locais. Eles desenvolveram uma habilidade reconhecida, que os tornava potenciais árbitros das questões controversas.

Os gêneros literários

Havia vários gêneros literários entre os glosadores: as glosas propriamente ditas, as additiones, as sumas, as quaestiones, as lecturae, os commentaria, o casus, as dissensiones doctorum, os brocardia e notabilia (LANGE, 1997). Em primeiro lugar as glosas: comentários ou explicações dos textos legais (libri legales) sem autonomia com relação ao livro comentado. Tomavam distintas formas: ou eram introdutórias ao texto (introductiones titulorum, introductiones legum), ou notas ao texto, ou estabeleciam as diferenças nos manuscritos encontrados, ou eram gramaticais e léxicas, ou explicavam os termos jurídicos. Quando as glosas eram menores, ou se referiam a passagens já glosadas, ou quando se restringiam a trechos ou pontos mais determinados, poderiam ser redigidas e publicadas com o nome de Additiones. Eram comuns e vários juristas escreveram estes complementos ou adições, ainda que não houvessem escrito glosas completas.

Além das glosas e additiones, existia a Suma. Segundo Calasso (1959, p. 23) os juristas imitaram o gênero dos teólogos. Ela já não acompanhava o texto palavra a palavra, mas prestava-se a uma sistematização de várias partes que diziam respeito a algum assunto ou tema. Algumas se reuniam em torno de temas, outras 'sumariavam' - sistematizavam - comentários gerais sobre livros inteiros, como a Suma de Azo sobre o Código. Ela não era um compêndio, o que chamamos um manual, mas uma 
'sistematização', isto é, uma tentativa de ordenar logicamente o assunto (CALASSO, 1959).

Questões (quaestiones) em geral diziam respeito a temas não encontrados nos textos legais, mas que deveriam com eles ser resolvidas. A questão era colocada ou para que o jurista apresentasse uma solução de um caso não previsto na lei, ou para que se pudessem tirar soluções diferentes baseadas em trechos diferentes do Corpus. Algumas questões procediam dos debates universitários: as queastiones disputatae. Outras eram as questões quodlibetales (quodlibéticas), formuladas livremente por qualquer um presente no debate e sobre qualquer assunto (daí seu nome, quod libet).

Essas coleções de Summae, Summulae, Brocharda, Distinctiones e Quaestiones "representam um sinal evidentíssimo de uma direção do pensamento que tendia à abstração, à função generalizadora típica da dogmática jurídica. A penetração sempre maior dos procedimentos lógicos da dialética no campo da ciência do direito deveria, obviamente, favorecer a afirmação da tendência à construção conceitual". (PIANO MORTARI, 1976, p. 205).

Finalmente, procedendo da própria experiência docente, havia as leituras (lecturae), os comentários (commentaria) e os casos (casus). As leituras, ou lições, eram geralmente 'relatadas', isto é, anotações de aulas. O comentário, como a leitura, distinguiase da glosa porque, como definiu Huguccio, canonista, "a glosa é uma exposição da sentença seguindo-lhe a própria letra, e atenta não apenas à sentença mas às palavras", enquanto o comentário era "uma exposição que não levava em conta a proximidade das palavras entre si, mas seu sentido" (apud LANGE, 1997, p. 139).

Com os comentadores, nos séculos XIV e XV, tornaram-se mais comuns ainda os pareceres e conselhos (consilia), os tratados e os próprios comentários. Os conselhos eram frequentemente encomendados por autoridades das comunas - no caso mais significativo da Itália setentrional - temerosas de serem responsabilizadas por suas decisões. De fato, nas comunas italianas as autoridades eram ou eleitas pelos corpos ou, para determinadas funções, que hoje chamaríamos de executivas, militares ou de justiça, contratavam-se estrangeiros de experiência e fama. Esses estrangeiros, supunha-se, seriam capazes de decidir de forma mais isenta, já que não estavam permanentemente comprometidos com os grupos, corporações, facções ou famílias das cidades. Nos casos de dúvida, os juristas eram contratados e contatados para dar sua opinião sobre os temas controvertidos. Giovanni Rossi (2003, p. 116, nota e p. 136) lembra que o conselho ou parecer não se afirmou com muita facilidade, ainda que fosse bastante comum. $\mathrm{O}$ gênero consilium dividiu opiniões, pois poderia tanto ser dado na forma de consilium pro parte, o que sugeria que houvesse sido vendido a um interessado, ou, dado como consilium pro veritate, mais aceitável, embora a distinção com o primeiro tipo nem sempre fosse fácil. 
Os comentadores são a 'segunda' grande escola medieval. Normalmente se considera Cino de Pistóia (1270-1336) o iniciador dessa corrente. Cino estudou em Bolonha com o filho de Acúrsio, e veio a ensinar em Siena e mais tarde Perúgia, onde foi professor de Bártolo - já citado diversas vezes - a grande expressão da escola. Note-se que Cino é praticamente contemporâneo de Guilherme de Occam (1290-1346) o grande franciscano filósofo do nominalismo. São contemporâneos da grande epidemia, a peste de 1348, do desterro de Avinhão e do Grande Cisma do Ocidente, referidos acima.

Os direitos, os temas

A doutrina medieval não distinguia da mesma forma que nós o público do privado, como de resto a própria sociedade e cultura medievais não faziam a diferença tão nítida que fazemos, fundados na filosofia moderna elaborada a partir do século XVII, entre a esfera da autonomia e a esfera da participação. Isso não quer dizer que não se distinguissem as coisas que só interessavam aos privados, por exemplo, na vida familiar ou de negócios. Quer apenas dizer que a 'esfera pública’ não era um lugar de encontro de pessoas individualmente consideradas, mas de pessoas já inseridas em algum 'papel' - na expressão jurídica status - e sempre participantes de algum grupo. Dessa forma, mesmo nas relações ditas privadas o que importava eram os papéis delineados juridicamente. Um era o papel do pai, outro o papel do rei, outro o papel de um mercador, mas qualquer um deles se definia por correlação com outros. Todas essas distinções apoiavam-se em distinções jurídicas (o status de cada um). Por isso mesmo, os juristas não se dividiam em privatistas e publicistas (LOPES, 2004, p. 92-96 e p. 210-211), já que tratavam do direito em geral. Dividiam-se melhor em legistas (ou seja, dedicados às leis, leges, direito romano, leis civis) e canonistas (dedicados aos cânones, direito canônico). Mesmo aí a divisão não era rígida, pois tanto uns quanto outros eram não poucas vezes 'doutores nos dois direitos' (doctores utriusque iuris). O que importa destacar é que a doutrina medieval visitou todos os temas que pôde: questões públicas e privadas, direito matrimonial e de família, sucessões, contratos, propriedade, posse e assim por diante. Destaco a seguir apenas três que foram objeto de longos debates: a soberania e o controle do poder, o conflito entre direito comum e direitos locais e, na esfera do direito que chamamos privado, os contratos e a propriedade.

É também sempre bom lembrar que o período do direito erudito medieval abrange, como já foi dito, vários séculos, nos quais as circunstâncias materiais, políticas e culturais mudaram muito. Se os inícios estão colocados no século XI e muito próximos à Querela das Investiduras (1075-1122) entre Gregório VII - e sucessores, e Henrique IV e sucessores, o período prossegue para abarcar no seu auge os séculos XIII e XIV (escola dos glosadores), chegando até o Cisma do Ocidente ou de Avinhão (1378-1414) (período 
dos comentadores). Lembremos que ao final do período tratado (século XV) Portugal já havia começado sua expansão marítima (1415, tomada de Ceuta), de modo que o comércio marítimo europeu deixava de ser simplesmente europeu, ou especialmente mediterrâneo, para iniciar a ganhar o Atlântico. Os comentadores, juristas da geração de Baldo (13271400), foram contemporâneos do Grande Cisma do Ocidente (1378-1418), dos primeiros humanistas florentinos, de Giotto (+1337) e até Brunelleschi (1377-1446). Há, portanto, uma variedade devida à própria extensão temporal do período. A seu lado, claro, há a divergência de escolas jurídicas (pense-se que há os juristas cisalpinos, os italianos, e os juristas transalpinos, os franceses), de escolas filosóficas (hás os universalistas e os nominalistas), de temperamento e de personalidade.

A soberania, o controle do poder e a organização do processo (ordo iudiciorum)

Um aspecto importante é o refinamento e a elaboração de regras impondo limites aos poderes de qualquer soberano. Em primeiro lugar, qualquer soberano estava sujeito a Deus e ao direito natural e disso derivavam doutrinas que punham em permanente xeque as pretensões de absolutismo ou irresponsabilidade dos príncipes. Se bem que os medievais reconhecessem em geral o poder de disposição de parte do direito pelo imperador, pelo rei e pelas próprias comunidades interessadas (o âmbito do direito positivo), algumas doutrinas lembravam permanentemente os limites a tal disposição, falando até no direito de os súditos se desfazerem violentamente dos tiranos por defeito no exercício do poder.

Em seguida estava sujeito às leis fundamentais, a principal delas a lei da sucessão, pela qual tinha ou não tinha título ao poder e à jurisdição (iurisdictio, imperium). Essa regra, para ser realmente uma regra, não estava à disposição do príncipe. A lei da sucessão era o que fazia alguém rei. Quem não a respeitasse, fazia-se tirano por defeito do título, muito embora com o tempo pudesse legitimar-se por um bom governo (pelo exercício). Daí a expressão famosa usada por Bracton (juiz da Corte inglesa, + 1268): "Lex facit regem”, “a lei faz o rei” (e não "rex facit legem”, “o rei faz a lei”).

Haveria também outros limites no exercício do próprio poder. Conta-se a história de uma cavalgada feita pelo imperador Frederico Barba-Ruiva na companhia dos dois doutores bolonheses Búlgaro e Martino. Frederico dirigiu-lhes a pergunta: “O imperador é senhor de todo o mundo?” A questão do domínio do imperador procedia de um trecho do Digesto (D. 14.2.9). Búlgaro disse que o imperador não era senhor (dominus) das coisas privadas; Martino disse que sim, sem qualificações. Diante da favorável resposta de Martino, Barba-Ruiva lhe teria dado seu cavalo de presente. Búlgaro lamentou-se com um trocadilho em latim: "Perdi um eqüino, porque respondi com eqüidade, e isto não foi equânime!" Esse episódio conservado na memória dos juristas medievais, mostra como 
eles eram consultados a respeito não apenas do título, ou da forma de exercício, mas também da extensão dos poderes (jurisdictio, imperium).

A limitação de poderes também se configurava pela aplicação do "quod omnes similiter tangit, ab omnibus comprobetur" (o que diz respeito igualmente a todos, por todos deve ser aprovado). Segundo Berman (1983, p. 221) desde o século XII os canonistas aplicavam o preceito às corporações eclesiásticas, das menores e mais singulares (uma abadia), às mais poderosas e largas (o bispo com seu capítulo). Como a concepção mais geral da vida fosse sempre coletivizada (corporativa), esse princípio valia para dificultar o surgimento de centralizações excessivas de poder na mão de uma só pessoa ou um só cargo.

Do ponto de vista dos juristas a questão colocava-se muitas vezes na glosa dos famosos trechos do Digesto (por exemplo, 'o que agrada o príncipe tem força de lei', D. 1.4.1). Quem afinal de contas tinha o imperium? Como ele havia chegado até os contemporâneos? Desenvolvera-se também entre os juristas, a partir da reflexão filosófica clássica e medieval, a doutrina do governo tirânico. Este foi percebido de duas maneiras: ou o governo tirânico pela ilegitimidade do título, ou pela ilegitimidade do exercício.

O pensamento jurídico-político tardo medieval é extenso. Desde João de Salisbury (1115?-1180), autor do Policraticus (1159), passando por Tomás de Aquino (1225-1274), Dante Alighieri (1265-1321) - autor do De Monarchia (1310), Egídio Romano (1243?-1315), Marsílio de Pádua (1280-1343?) - famoso pelo seu Defensor pacis (1324), Guilherme de Occam (1280?-1349) - com o Brevilóquio sobre o principado tirânico, até os conciliaristas que defendiam, no século XV, a supremacia dos concílios sobre os papas, há uma enorme produção. Toda ela discute os limites do poder que, no caso dos príncipes seculares apoia-se frequentemente na ideia de que o príncipe é 'legibus solutus', ou seja, dispensado (desligado) das leis, e no caso do papa apoia-se na ideia de que sendo ele vigário de Cristo é chefe e cabeça (caput) da Igreja.

As tentativas de colocar os senhores políticos acima dos respectivos corpos sociais e dispensá-los de prestações de contas foram rechaçadas por diversas linhas de pensamento. Além dessa discussão 'filosófica' sobre as origens e as justificativas do poder, havia discussões jurídicas sobre os conflitos de jurisdições e poderes efetivamente existentes (conflitos entre comunas e imperador, entre imperador e papa, entre rei e corporações locais, entre príncipes entre si, entre o âmbito e validade do direito civil - romano - e o direito canônico, entre o direito comum - ius commune - e os direitos especiais - iura propria etc.). E nesse debate muitos foram os juristas que participaram, assim como muitas foram as instituições legais criadas.

Bártolo, sempre ele, enfrenta muitas dessas questões e lhes dá uma formulação jurídica sempre referida. Em diversos tratados o tema do poder político e de sua extensão veem 'resolvidos' na pena do professor de Perúgia, especialmente 
nos tratados "Sobe a Tirania" e "Sobre o governo das cidades". Segundo Ryan (2000) a vantagem das soluções de Bártolo estão no seu caráter prático, já que como jurista interessava-lhe a solução de controvérsias reais. Por isso, segundo a análise de Ryan, o que interessa Bártolo ao formular sua 'doutrina da soberania' (soberana é a cidade que não reconhece um superior), o que está em jogo não é tanto - como se pensava antes - a disputa das comunas ou repúblicas italianas com o imperador, mas o reconhecimento de que a cidade deve ser responsável por instituir seus próprios mecanismos de solução de conflitos internos. O problema concreto a enfrentar não era tanto a submissão ou não ao imperador, mas a definição de quem, em caso de guerra civil ou revolta, poderia pôr fim ao conflito. A resposta de Bártolo seria, a cidade mesma, considerada como 'respublica' e como 'corporação'. Ela era autônoma, e por isso deveria saber distinguir o interesse de suas facções do seu próprio interesse (o bem comum).

Naturalmente esse - o bem comum - é um tema fundamental, já que no tratado sobre a tirania, a referência o bem comum é o ponto chave. O que define o tirano - pelo exercício - é seu afastamento do bem comum:

Digo que é tirano pelo exercício aquele que pratica ações tirânicas, isto é, suas ações não tendem ao bem comum, mas àquele próprio do tirano. Isto não é próprio do direito de governar. A maneira mais fácil de demonstrar isto, porém, tem-se quando chegamos aos atos particulares, atos que na sua maior parte foram expostos no livro primeiro deste tratado. Eles consistem em afligir os súditos. Tais atos são claramente enumerados por Aristóteles na Política, Livro V, e por Egídio no livro Do regime dos príncipes. (De Tyrano, VIII).

Mas não só de interpretação dos textos romanos e de arbitramento de disputas em guerras civis ou revoltas vivia a doutrina jurídica. Outro ponto importante diz respeito à racionalização dos processos decisórios. Neste sentido, a determinação da 'ordem do processo' (a ‘ordo iudiciorum'), principalmente a partir do processo canônico, pode ser contada como uma forma de controle do poder. A sedes materiae da limitação dos governantes num sistema político definido como primeiramente jurisdicional (isto é, em que o poder político se exerce em primeiro lugar em nome da justiça e sob a forma de juízos) localiza-se na ordenação do procedimento, dos tribunais e da jurisdição. Nesses termos, o direito tardo medieval também produziu muita coisa e não de pouca importância é a contribuição dos canonistas.

A forma estrutural que os livros de direito canônico adquiriram depois da famosa compilação feita por Raimundo de Peñaforte para Gregório IX (1234) é relevante para entender o processo. A coletânea, promulgada oficialmente com a bula Rex pacificus, ficou conhecida na história como Decretais de Gregório IX ou Livro das Extravagantes 
(ou simplesmente Liber Extra) dividiu-se em cinco partes: I - fontes de direito, poderes e competências de bispos, clérigos e tarefas do juiz (iudex); II - direito processual (ordo iudiciorum); III - direitos patrimoniais e sacramentos (clerus); IV - matrimônio (connubia) $\mathrm{V}$ - delitos e penas e processo penal (crimen). Como se vê, as duas primeiras partes (conhecidas simplesmente como iudex e iudicium) ao definir, determinam e limitam os poderes das autoridades. O fato de os dois primeiros livros serem justamente sobre o iudex e o iudicium (ordo iudiciorum) é indicativo da força da ideia jurisdicional do direito. É a tese de Pennington (1993, p. 119-164) de que vários direitos 'subjetivos' e várias garantias fundamentais desenvolveram-se, sob outra nomenclatura, claro está, debaixo da proteção do ordo iudiciarius. Este consistia no procedimento burocratizado da cúria romana que se foi estendendo a toda a jurisdição eclesiástica, por força da apelação que se poderia fazer a Roma, a Sé Apostólica. Ouvindo os recursos das partes, Roma anulava processos inteiros em que não se houvesse respeitado o mínimo de oitiva de partes e outros cuidados hoje familiares (o 'devido processo'). Isto restringia o arbítrio dos juízes locais e ao fim, rotinizando a própria cúria, estabelecia limites quase que autoimpostos. O aumento da importância da ordo iudiciorum deve-se, também, ao aumento da autonomia dos particulares na elaboração de seus 'negócios', segundo a opinião de Calasso (1959, p. 320). Na sua interpretação o processo (ordo) ganha relevo na medida em que os mecanismos de solução de controvérsia tradicionais dependiam de laços de solidariedade intrafamiliar, enquanto no período áureo da história das comunas (e também da burocratização da Igreja) o mecanismo de tutela dos direitos dos particulares passa a ser, por excelência, o processo. É toda a longa história do abandono do processo ritual (ordálios, duelos etc.) para o processo formal.

Segundo Pennington a ordem do processo foi inicialmente tratada como uma rotina de conveniência, que se poderia alterar por simples disposição de vontade do príncipe, bispo ou papa. A certa altura começaram os juristas a indagar se algumas dessas regras não provinham da razão natural. Se assim fosse, algumas delas poderiam ainda assim ser modificadas pelo príncipe, mas para isso seria preciso que ele oferecesse outra razão natural forte.

Caso exemplar de controle das disputas pelo discurso jurídico foi o da Revolução de Avis em Portugal. Abrira-se em 1385 uma crise na sucessão, relativa, portanto, à lei fundamental do reino. E como diz Caetano (1992, p. 445), "todo o debate ao redor da sucessão foi jurídico". As Cortes de Coimbra, reunidas em 1385 procederam a uma inquirição para determinar a legitimidade sucessória, terminando por excluir, com argumentos jurídicos, todos os pretendentes: cada um deles tinha um defeito de título distinto. Logo, a coroa encontrava-se vaga, o que autorizava as mesmas Cortes a "nomear, escolher, tomar e receber alguma pessoa digna", recaindo a escolha sobre D. João, Mestre 
de Avis. Feita a eleição, foi necessário fazê-la referendar pelo papa, árbitro final das disputas entre príncipes cristãos, o que só veio a acontecer em 1391.

Uma vez eleito D. João, diz Caetano que as Cortes lhe apresentaram pedidos para sanar, para o futuro, dificuldades semelhantes às que ocorreram no reinado recémfindo de D. Fernando. Para tanto, propuseram que o rei governasse sempre com Conselho, que o Conselho fosse composto de prelados, fidalgos, letrados e cidadãos de Lisboa, Porto, Coimbra e Évora. Dentro do Conselho sugeriram que houvesse um chanceler, um tesoureiro, um encarregado da fazenda, um responsável pelo desembaraço (desembargo) das demandas de graça e outros 'desembargos', cada um deles levando a questão de sua competência para resolução conjunta. Esse conselho, diz Caetano seria uma verdadeira 'deputação permanente' junto do rei. Finalmente, pediam que para as grandes decisões públicas, o rei convocasse Cortes, "por que é de direito que nas cousas que a todos pertencem e de que todos sentem carrego sejam a ello chamados" (CAETANO, 1992, p. 456-458). Ora, essa última afirmação era sustentada (de direito) pela lei conservada no Código de Justiniano e já mencionada acima: "ut quod omnes similiter tangit, ab omnibus comprobetur" (C. 5, 59, 5). ${ }^{6}$

Pode-se dizer em resumo que a teoria da soberania medieval era temperada de fato pela existência, e de direito pelo reconhecimento de diversos poderes sociais que se limitavam reciprocamente. $\mathrm{O}$ limite não era, como no direito moderno, o dos direitos do indivíduo perante o poder social (político, em primeiro lugar), mas dos direitos dos corpos e 'povos' diante de outros corpos ou outros poderes. As disputas entre Igreja e 'Estado' encontra-se em toda parte como um exemplo de conflitos de jurisdição, mas também se encontram em toda parte os conflitos entre comunas (cidades, câmaras) e príncipes, entre diversas corporações etc.

Um ius commune: conflito de leis, direito local, privilégios

Uma das características do direito medieval é, como diz Grossi no texto de abertura deste volume, o papel particular que a lei desempenhava. A ideia dominante não era a da lei como expressão de uma vontade, e sobretudo não exclusivamente a expressão da vontade do legislador. No estudo, o que aparecia então eram direitos, antes que direito. O termo direito (ius) e o termo lei (lex) conviviam com vários significados. Todos reconheciam que eram palavras ambíguas. Dar os significados das palavras, como foi visto, era também pôr ordem nas ideias. Era preciso inicialmente distinguir com quantos significados se trabalhava e ao fazer isto seria possível constituir campos. O procedimento já havia sido usado pelos professores de direito no período clássico do direito romano. As

\footnotetext{
"Aquilo que a todos concerne igualmente, por todos deve ser aprovado".
} 
Instituições de Gaio, e as de Justiniano baseadas naquelas, davam a ideia geral da lei e do direito e em seguida listavam as formas da lei e do direito.

Para começar havia dois direitos que se podia estudar separadamente ou em conjunto: o direito canônico, e o direito civil cujo eixo principal era o direito romano. Na linguagem da época, estudavam-se cânones ou leis. Isso constituía o direito comum, ou seja, aquele direito que vigorava em toda parte. $\mathrm{O}$ direito canônico valia para a Igreja toda, acima das fronteiras locais por definição. $\mathrm{O}$ direito romano valia tanto por ser o direito do Império, quanto por ser um depósito de razão também acima das fronteiras locais. Na Itália, estudava-se também o direito 'feudal', no Liber feudorum (os costumes e normas feudais da Lombardia). Aceitava-se, portanto, que haveria um núcleo 'racional' descoberto e estudado ao tratar do direito romano, e haveria um núcleo tradicional que se poderia elaborar debruçando-se sobre os direitos particulares e locais. ${ }^{7}$

$\mathrm{O}$ direito romano era estudado de duas perspectivas: (i) primeiro como um depósito de regras de razão (ratio scripta) no qual se havia acumulado um saber a respeito da aplicação de normas e constituído tipos de explicação de muitos afazeres humanos; (ii) segundo, também poderia ser estudado como lei positiva, isto é, como lei vigente e aplicável, pela boa razão de que o Império havia sido transmitido para, ou restaurado pela Cristandade (traslatio imperii). Mesmo nos lugares em que o Imperador nunca teve poder propriamente (França, Península Ibérica), entendia-se que os reis eram ‘imperadores' em seus territórios. Não surpreende, pois, que o direito romano tenha sido especialmente aceito pelos tribunais régios sob tal pretexto. Era possível argumentar de duas formas, pois: ora tomando as regras do direito romano como exemplares de um raciocínio válido, especialmente tomando-as como exemplares de um saber aceitável, e neste caso a regra funcionava como premissa de razão, ora tomando-as como regras positivas, aceitas e recebidas. No primeiro caso, invocavam-se as leges como se fossem 'princípios', isto é, normas muito gerais, frequentemente usadas fora do campo específico para o qual haviam sido criadas. Assim, a regra (ou princípio) já mencionada - "quod ad omnes tangit, ab omnibus..." - foi utilizada em mais de uma circunstância para defender a participação geral nas decisões coletivas (BERMAN, 1983, p. 21), quando originalmente dizia respeito a conflitos entre herdeiros. Outras regras diretamente tiradas dos textos de Justiniano sobre os poderes do imperador eram usadas como direito vigente, tanto para sustentar quanto para limitar o mesmo imperador romano-alemão ou os reis, ditos 'imperadores em seus reinos'.

Devido à não divisão rígida entre direito privado e direito público, também era possível que regras que hoje veríamos como exclusivamente 'privadas' fossem usadas

A bibliografia sobre o direito canônico é imensa. Para introduções contemporâneas e sérias ver especialmente R. H. Helmholz (1996). 
para resolver questões políticas ou de direito 'público'. Pense-se no caso das comunas italianas, o caso mais típico de todos, cujo nascimento era como o de uma associação privada, reconhecida e aceita pelo senhor local, rei, imperador, ou mesmo papa, como uma corporação. Este reconhecimento dava-lhe uma existência permanente que ia além da existência de seus 'sócios', e lhe concedia, como a toda corporação em princípio, poderes de jurisdição - de determinar suas próprias regras, de decidir conflitos internos e assim por diante. A rígida separação entre público e privado não estava na origem da corporação, pois algumas pessoas, grupos ou famílias que não tinham, por definição, nenhum poder propriamente - em nossos termos - político, passavam a tê-los em um certo ponto. Com isto, porém, a comuna não deixa de ser uma corporação a mais, que também não podia, por não ser absorvente de tudo o que estava no seu território, invadir a esfera das outras corporações que com ela conviviam - uma universidade, uma catedral com seu capítulo, um mosteiro, uma corporação de ofícios.

Pluralismo, direito comum e direitos locais. Essas diferenças vieram a exigir regras que definiam as respectivas jurisdições, os conflitos de jurisdição e assim por diante. Nem sempre essas regras eram explícitas no direito romano (que pressupunha a unidade de jurisdição imperial), especialmente o direito compilado por Justiniano (de um império centralizado). Havia, portanto, um grande campo de elaboração para os juristas, que do seu baú deveriam tirar coisas novas e velhas para resolver questões rotineiras e tradicionais assim como questões novas.

Como compatibilizar direitos locais e direito comum? A questão era um pouco diferente conforme o lugar. No território submetido ao chamado Sacro Império, ou Império Romano-germânico, a solução exigira compatibilizar estatutos (direitos locais, direitos municipais, direitos nacionais escritos), costumes (direitos locais não escritos) e privilégios (direitos especiais) com o direito comum (romano). A aplicação poderia ser simultânea, desde que o direito local estivesse em consonância com o comum. Em outros lugares, como na França, Espanha (naquela altura Castela, Aragão...) e Portugal admitiase a precedência do direito local e aplicação subsidiária do direito romano. O fato é que o direito comum serviu para 'corrigir' os costumes e direitos locais, quando se alegava que tal ou qual costume ou estatuto deveria ser interpretado de modo a não violar as regras da razão e da equidade. Como o direito romano servia de fonte para regras de razão, sua influência foi determinante - na esfera erudita dos tribunais e cortes régios para progressivamente uniformizar os direitos europeus. Já foi mencionado antes que as Siete Partidas (Afonso X, 1254) tiveram grande influência do direito comum (romano e canônico). Em Portugal convém lembrar que o movimento corporativo urbano foi muito menor do que na Itália ou na Flandres, seja pelo isolamento geográfico, seja pela relativa pobreza do reino em comparação com o coração mercantil e agrícola da Cristandade. Assim, há quatro cidades que adquirem foros próprios, ou seja, estatutos próprios: Porto, 
Coimbra, Lisboa e Évora e que servem de modelo para as outras vilas. A comuna italiana é a câmara - ou senado da câmara - portuguesa.

Outro caráter do ius commune - sua erudição - revela-se na crença e no uso, ao final da Idade Média, de um critério de interpretação chamado communis opinio doctorum. Em caso de divergência ou disputa indicava-se como se hierarquizavam as fontes doutrinais. É o que fazem as Ordenações em Portugal: a unanimidade dos doutores valeria como lei; na falta de acordo, valeria a interpretação da Glosa de Acúrsio; em caso de lacuna na Glosa, deveria ser aplicada a opinião de Bártolo (cf. Ordenações Filipinas, L. III, t. 64, 1). Villata (1980, p. 331-332) resume o destino desse direito comum erudito no confronto com os direitos locais, dizendo que passara de uma absoluta preeminência ao posto de fonte subsidiária no final da Idade Média. Esse caráter erudito dependia da existência de um grupo social cosmopolita, como eram os juristas, capazes de entender-se em uma língua culta (o latim), dentro de uma linguagem disciplinar específica (o direito comum, romano e canônico) e de se socializarem em centros urbanos determinados (Bolonha, Orleãs, Salamanca, Coimbra, etc.). Com tudo isso a funcionar, o direito comum pairava acima dos estatutos locais, contingentes e variados, servindo de instância unificadora última, antes de se apelar ao direito natural. Por isso, assim como a 'razão' serviria de critério de ‘correção' dos maus costumes, também o direito comum erudito desempenhava papel semelhante.

Contratos e pactos, propriedade e posse

Recordando sempre que o período do direito comum na Idade Média abrange mais de três séculos, é possível ver que o tratamento de um tema como o da posse e da propriedade, como também dos contratos e das sucessões, sofre diversas mudanças. Umas são devidas às próprias condições locais, aos costumes que se preservam e precisam ser compatibilizados com o direito comum, outras às formas próprias de realizar negócios do estamento dos mercadores em distintas partes e assim por diante.

Pode-se falar de uma discussão em torno dos contratos. É de se destacar que não havia apenas transferências de terras em forma de venda ou doação, mas também aforamentos e locações perpétuas, e sobretudo muitos negócios novos nas cidades: negócios sobre prédios urbanos, negócios mercantis, sociedades, empréstimos, seguros. Para todos eles era preciso determinar uma natureza (uma finalidade e uma forma). Sociedades entre mercadores poderiam ser realmente sociedades com formas diversas de distribuição de lucros, ou formas fraudulentas de empréstimos (usura) ocultadas pelo uso de um contrato de sociedade sem que houvesse realmente intenção de se associar. $\mathrm{O}$ mesmo poderia dar-se com contratos de garantia ou seguro. Assim, a análise da finalidade e da estrutura do negócio era importante para determinar sua validade e conformidade 
com o próprio direito. O consenso e a promessa, de fato valorizados pelo ius commune, não levavam, porém, a uma doutrina contratualista geral de caráter voluntarista.

Munidos desses conceitos, e travando em torno deles batalhas doutrinais, os operadores intelectuais, isto é, os intérpretes do ius commune articularam instrumentos que foram usados até que a doutrina predominante ou exclusivamente consensual, desenvolvida por humanistas e jusnaturalistas, viesse a tomar-lhes o lugar nos séculos XVII e XVIII, entrando finalmente no direito contemporâneo.

Não havia uma 'categoria geral' do contrato, coisa que só com o advento do humanismo, ao longo do século XVI, começa a aparecer (BIROCCHI, 1997, passim). A partir do século XVI e especialmente no século XVII começam as definições gerais de contrato como 'conventio cum casa'. Os medievais, porém, combinaram os contratos típicos do direito romano (verbais, reais, consensuais e literais) com suas próprias necessidades. A doutrina medieval elaborou diversas categorias dentro das quais se resolveram questões contratuais: Birocchi aponta para duas especialmente importantes, a do vestimento dos pactos e a da causa.

Quanto ao primeiro ponto (o dos pactos), distinguiam eles a faculdade de prometer (universal) da faculdade de obrigar-se (particular), e, seguindo em parte as distinções romanas, diferenciavam contratos (exigíveis) de outras formas de 'promessa' (não exigíveis). Aceitavam, pois, de modo geral aquilo que as fontes romanas chamavam de pactos nus (pactum nudum, pacta nuda), incapazes de gerarem efeitos jurídicos (ações). À falta de uma teoria geral do contrato no corpus iuris, elaboraram uma teoria do vestimento dos pactos, de modo a permitir que promessas fossem exigíveis. O pacto nu era inexigível, mas o pacto vestido gerava direitos e ação.

Nos textos romanos clássicos, contratos eram uma coisa, pactos outra. Os medievais distinguem nos pactos duas categorias. A primeira a dos pacta nuda, iguais em tudo à concepção clássica, compreendendo, pois, hipóteses ineficazes para produzir ação; a segunda é, ao contrário, uma categoria totalmente nova na qual se recolhem as espécies típicas e plenamente acionáveis do direito romano, chamadas significativamente de pacta vestita. A stipulatio romana torna-se, pois, no léxico dos glosadores, um pacto vestido verbis; o mútuo é um pacto re vestitum, e assim por diante. (VOLANTE, 2001, p. 3).

Baldo, no século XV, diria que "a obrigação natural depende de um fato - o consenso -, enquanto a obrigação civil depende de uma solenidade jurídica".

O trecho de Volante reproduzido acima expressa justamente isto: a stipulatio, uma promessa solene, é alargada a ponto de ser a vestimenta de qualquer promessa. Essa extensão da stipulatio para abarcar qualquer promessa (e dar a qualquer promessa solene o caráter de obrigação exigível) levava a conclusões paradoxais, relatadas por Birocchi. Como poderia uma forma verbal (a forma solene da stipulatio) continuar a ser 
o fundamento de exigibilidade do pacto à medida que desaparecia a mesma fórmula e se faziam contratos escritos (BIROCCHI, 1997, p. 70 et seq.)?

É nesse contexto que outra doutrina, a doutrina das causas, precisava afirmar-se. Ela pressupunha o uso dos conceitos de causa material, causa eficiente, causa formal e causa final. A causa final (isto é, a função ou finalidade) unida à causa formal (isto é, à estrutura) dá propriamente a substância da coisa (forma dat esse rei). Nos contratos, sua causa final é de sua substância e, portanto, dá-lhe a natureza. Por exemplo, uma compra e venda, sendo uma troca de coisa por dinheiro, com a finalidade de transferir o equivalente (sinalagma) entre comprador e vendedor, naturalmente, por sua causa final, deve conter certas condições e cláusulas. A causa determina, pois, a natura contractus. Assim, a vontade de obrigar-se (causa impulsiva) encontrava no ordenamento jurídico os tipos de obrigações aceitáveis, pois havia tipos-ideais - para falar com as anacrônicas palavras de Max Weber - de negócios, os contratos típicos ou nominados. Esses tipos distinguiam-se cada um por sua causa finalis. As causas dos contratos também poderiam distinguir-se em causas naturais (causa naturalis) e causas civis (causa civilis). A primeira corresponderia à causa 'racional', ao que talvez hoje chamássemos de um fundamento ‘antropológico' (é da natureza da espécie humana... todos os grupos... etc.). A segunda era de direito positivo e, portanto, correspondia àquilo que em direito (civil, canônico ou local) se poderia aceitar. A primeira não gerava por si obrigação, a segunda sim.

Mas houve diferenças ao longo do tempo. Calasso acredita que os glosadores desenvolveram uma noção de causa e os comentadores outra.

O ponto de distinção é esse: enquanto nos séculos XII e XIII a ciência aprofundara o problema da causa considerando-o do ponto de vista do ordenamento jurídico, agora [no tempo dos comentadores] pelo contrário esse conceito se estuda preponderantemente do ponto de vista da vontade do sujeito. (CALASSO, 1959, p. 287).

A complexidade das doutrinas medievais não era pequena.

Grossi (1968) aponta para algumas questões centrais do tema da propriedade. Em primeiro lugar, o direito romano voltava a ter influência em uma Europa cuja maior preocupação já deixara de ser a reconquista da terra, para tornar-se o tráfico, a circulação (GROSSI, 1968, p. 132). Em segundo lugar, as fontes romanas falavam de um dominium muito diferente da situação realmente vivida pela Idade Média 'pré-Irneriana' (GROSSI, 1968, p. 144-145); é que se haviam formado diversas 'formas' de relação dos homens com a terra. Ao longo do período anterior ao 'renascimento' jurídico formaram-se situações diversas como a dos colonos, precários, feudatários, locatários de longo prazo, todas depois abrigadas sob uma forma de dominium, o dominium utile. O dominium mesmo dividiu-se, como diz sumariamente Bártolo, em dois: o domínio útil e o domínio 
direto (eminente). Os dois se transmitiam independentemente e ambos geravam direitos diferentes, sem que tudo se resumisse a um proprietário exclusivo. Assim, chamava-se de propriedade a relação permanente com a terra (a coisa corpórea por excelência), que poderia ser defendida de diversas maneiras.

O mesmo Grossi mostra, porém, como a definição a que chegou Bártolo não foi realmente pacífica e nem fácil de se atingir. Para alguns franceses (ultramontanos, dialéticos) o domínio era unitário, na linha que se descobria nos textos romanos (GROSSI, 1990, p. 395). É que a situação do detentor do domínio útil poderia ser confundida com a do usufrutuário de que falavam as fontes mandadas compilar por Justiniano. Foi necessário, portanto, distinguir o usufrutuário do proprietário de domínio útil, o que se fez em torno do tema do feudo. Grossi dá início ao seu ensaio sobre a elaboração dos feudistas observando que a matéria feudal era inicialmente desprezada em Bolonha (GROSSI, 1990), mas que afinal a distinção entre os dois domínios tornou-se depois de uso comum, ou, nas palavras de Andrea de Isernia, opinião comum (GROSSI, 1990, p. 181). Ao fim da Idade Média, Zasius, homem de transição (GROSSI, 1985, p. 374) procura compor duas vertentes de interpretação do domínio: de um lado já enfatizando a noção de abuti contida na 'propriedade' e, por isso, calcando-se sobre o sujeito; de outro, aceitando de forma plena a divisão dos dois dominia, direto e útil. Em resumo, embora se possa reconhecer o fato da divisão da propriedade (útil e direto), e embora se possa conceder que de modo geral a disciplina jurídica da propriedade parte das coisas e não dos sujeitos, as pesquisas de Grossi mostram que houve escolas e mudanças ao longo do período.

Não apenas de propriedade, mas também de posse se tratava. E aqui a discussão dava-se em primeiro lugar em torno da definição mesma de posse. Conforme relatado por Volante (2003, p. 1-39) a doutrina jurídica medieval começava por apoiarse no conceito encontrado nos textos romanos (D. 41, 2, 1, de acquirenda vel amittenda possessione, l. Possessio appellata est), para ganhar depois uma dinâmica própria. Piacentino aceitava a definição romana que se incorporara à Summa Trecensis, mas João Bassianus mais tarde a definiria autonomamente, segundo consta da Glosa: "Pode-se definir a posse como o direito de ter consigo a coisa" (definire autem potest sic, secundum Ioannis, possessio est ius quoddam rem detinendi sibi). Seguindo a mesma exposição de Volante, pode-se acompanhar o desenvolvimento da polêmica: Azo (+ 1230?), aluno de Bassiano, discordava de seu mestre porque dizia que a posse era um estado de fato, não de direito (ius). Seguiu-se depois a discordância de Jacques de Ravigny $(+1296)$, para quem a posse também não era um simples fato, como poderia sugerir a leitura de Azo. Ao lado dessa discussão, debatia-se também quantas espécies de posse poderia haver e qual a diferença entre elas. Falava-se da posse natural em contraste com a posse civil, por exemplo.

Grossi (1988a) sintetiza a relação entre domínio e posse: 
O domínio útil é (...) antes de tudo a tradução, em termos jurídicos, de uma mentalidade. É a mentalidade do primado do efetivo, é a mentalidade 'possessória' da Alta Idade Média que ainda domina, como imperiosa constituição material do mundo dos glosadores e comentadores. Mais ainda, no fundo um modelo agrário e não urbano de dominium, em que o princípio romanista pelo qual se tem a propriedade apenas na relação entre um sujeito e uma res corporalis parece, de fato, especificar-se na relação entre sujeito e terra, res frugifera por excelência e por excelência fonte de toda utilitas. Aplicável ainda aos mais variados bens imóveis, o domínio útil evoca porém sobretudo uma paisagem agrária, com uma forte dialética entre depositário da titularidade proprietária e quem exerce a empresa agrícola sobre o bem terra. (GROSSI, 1988a, p. 241).

A longa citação será desculpável em nome da clareza e síntese que o texto demonstra. Longas e técnicas elaborações a respeito do domínio, da posse, das servidões, procurando estabelecer o esquema dentro do qual, como diz Grossi, distinguem-se e convivem o titular de um domínio com o titular de um "empreendimento" sobre o mesmo bem. De toda sorte, vê-se que a produção e o debate a respeito do tema eram grandes e variados.

A variedade de situações jurídicas da terra incluía terras livres (alodiais), terras nobres (isentas eventualmente em relação à coroa), terras comuns, sobre as quais qualquer um poderia exercer direitos que não impedissem os direitos alheios (como, por exemplo, o de pastagem) e assim por diante (GILISSEN, 1988, p. 649, nota de António M. Hespanha).

Seja nos contratos, seja nos pactos, seja na posse, seja na propriedade notase um traço geral. Não se derivava da 'natureza humana' uma disciplina jurídica unívoca. Nem mesmo a 'natureza humana' como regularidade gerava 'direito natural' algum, sobretudo no âmbito de coisas tão contingentes e variadas como sejam a propriedade (como deter e usar as coisas que têm valor econômico) ou das obrigações (como trocar essas utilidades). A distinção recorrente entre o natural e o civil é testemunha da distância que há entre essa 'civilização' e a civilização moderna, para quem a propriedade e a autonomia privada são explícita e frequentemente tratadas como direitos naturais e inalienáveis.

A particular experiência inglesa

Também a Inglaterra conheceu a profissionalização e especialização do direito, o que a insere no mesmo processo da civilização medieval, embora de forma particular. Ali o treinamento dos juristas não foi nas universidades, mas no próprio foro, 
junto aos juízes reais. Van Caenegem lembra que no continente o direito era ou europeu (comum, o direito romano e o direito canônico) ou era local, isto é, dominado por costumes ou estatutos particulares (CAENEGEM, 1989, p. 88). O direito comum (ius commune) era universitário, escolástico e o direito local era positivo. Entre os ingleses o direito comum (common law) era o direito positivo, o costume geral da terra, conforme entendido, aceito e aplicado pelos juízes do rei.

$\mathrm{Na}$ Inglaterra o instrumento precoce e privilegiado de unificação do direito foram os tribunais régios antes que as universidades, já que em função da conquista normanda (Guilherme, o Conquistador, 1066) deram-se condições para que a autoridade do rei fosse mais eficaz. A feudalização geral da vida, trazida pelos normandos, fazia do rei o senhor a quem todos se subordinavam por laços de vassalagem e pela detenção da terra conquistada. Desenvolveram-se, assim, mecanismos pelos quais o rei intervinha nas disputas de terra, estabelecendo um direito comum (common law) capaz de impor-se sobre os costumes locais e ao mesmo tempo rechaçar a importação de um direito romano.

A intervenção real concentrou-se inicialmente nas questões envolvendo disputa de terras, posse e propriedade. Em caso de conflitos, um juiz era enviado ao local para ouvir pessoas conhecedoras dos fatos, que juravam dizer a verdade: daí seu nome, jurados. Os jurados, o júri, portanto, substituía o duelo e o ordálio e introduzia no processo a verdade empírica. Naturalmente, os fatos eram determinantes, pois a posse, a propriedade útil da terra, deveria, o quanto possível, ser preservada. Por isso, quando houvesse um esbulho ou uma turbação recente da posse, uma 'nouvelle dissesine', a vítima poderia pedir a intervenção régia, na forma do júri presidido por um dos juízes do rei.

Juízes itinerantes foram enviados pelo rei para organizar os processos, ouvindo os jurados a respeito das queixas que lhe chegavam. Tais juízes faziam-se acompanhar de outros oficiais, chamados, em geral, de serjeants of law. O treinamento desses serjeants of law deu origem à educação jurídica inglesa. Não que os ingleses desconhecessem o direito romano. De fato, no texto conhecido sob o nome de Bracton - juiz da cúria régia - (De legibus et consuetudinibus Angliae de 1256), há inúmeras referências ao direito romano. Lia-se direito romano na universidade inglesa. Mas tratavase de uma disciplina geral de cultura, para formar os artistas, não os juristas. $\mathrm{O}$ direito romano propriamente dito não pertencia ao repertório dos juristas ingleses de forma imediata. O direito inglês desenvolveu-se no fundo a partir do direito feudal e dentro de seus quadros, nos quais fidelidade, boa-fé, e reciprocidade eram elementos naturais. A ideia de relação, diz Caenegem (1989, p. 89), dominava o pano de fundo do direito inglês.

$\mathrm{O}$ aprendizado preparava diretamente o candidato a tornar-se um dos sujeitos que punha em andamento a máquina real de fazer justiça. Acompanhavam o bench, o tribunal, e aprendiam como praticantes a arte de julgar e organizar os pedidos e o processo. Ao final da Idade Média, isto é, no início do século XV, é que se tem notícia 
de que o estudo estava realmente organizado nos Inns of Court, os pátios dos tribunais, em Londres. Mas mesmo então, quando já se pode dizer, segundo Baker (2000, p. 6) com evidência documental, que há um ensino perfeitamente estabelecido, o treinamento é exclusivamente prático-jurídico. Isto não significa empecilho à presença de grandes mentes ou mesmo mentes refinadas e eruditas, já que se sabe que Thomas More proferiu lições em um dos Inns. Por esta razão, passou-se a chamar os Inns of Court de "terceira universidade inglesa", já no século XVII. É que ao lado de Oxford e Cambridge, essas escolas de 'juristas práticos' era também a escola de uma elite política cuja carreira se desenvolvia nos tribunais. Baker informa também que desde 1280 já se organizara o aprendizado jurídico, mas diferentemente da Europa continental, mesmo nos Inns of Court alunos e professores não formaram uma corporação, não criaram uma pessoa jurídica e não se encantaram com o direito erudito romano.

Mesmo assim, esses candidatos a uma carreira judiciária eram letrados, detinham funções típicas de gente letrada, os 'clérigos', e por isso eram 'clerics', clerks, como até hoje se chamam os funcionários da justiça (e em geral os que trabalham em escritórios). Como gente letrada, estavam obrigados a dominar o latim e o francês. O latim era a língua na qual se anotavam os termos do processo e as decisões, o francês a língua em que se sustentavam os pedidos. Claro, tratava-se de um francês que pouco ou nada tinha a ver com o francês de Paris, pois era uma sobrevivência da língua trazida pela corte de Guilherme. Mesmo assim deixou muitas marcas no inglês jurídico, a começar pelo mais famoso remédio criado na common law, o seu verdadeiro início, o mandado (breve, writ) de nouvelle dissesine, ou o mandado de mort d'ancesteur.

Foi na corte da chancelaria que o direito erudito pôde ter alguma influência na cultura medieval inglesa, à parte da common law. A corte de chancelaria era o lugar para onde o rei mandava os casos que os juízes de common law não podiam resolver. Era formada em torno do lorde chanceler, normalmente o arcebispo da Cantuária, ou seja, o primaz (o primeiro em honra) da Inglaterra. Cantuária era a mais antiga sé episcopal inglesa, lugar do assassinato de Agostinho da Cantuária, missionário cristão (durante o reinado de Henrique II; tornou-se também o lugar de assassinato de Tomás Beckett, no Natal de 1170). Na corte da chancelaria dominava gente treinada no direito canônico, e o processo pouco ou nada tinha a ver com a common law. Ali se desenvolveram novas ações e novos fundamentos para as ordens reais. No período medieval, era uma corte especial, de privilégio, um tribunal apartado para questões e pessoas específicas em princípio.

No lugar dos textos de direito romano, o que a cultura jurídica inglesa passou a cultivar foram seus próprios textos e os precedentes das decisões. Devido à presença do júri, e, por isso mesmo, de processos orais de audiência e julgamento, não era fácil reter os precedentes. O que se poderia era sumariar o pedido, os fatos, a ordem do rei, a decisão. Isto constituía o 'record'. Havia também o registro das ordens régias (register 
of writs). Mas muita coisa era transmitida por tradição oral. Tudo isto criou na Inglaterra uma tradição particular, cuja especificidade não deveria enganar a ponto de separá-la do desenvolvimento geral da própria cultura do Ocidente latino. Os contatos eram muitos: não apenas pela via do comércio e da própria Igreja, com seus clérigos e seu direito canônico universal, mas também pela racionalidade que em última instância poderia ligar-se ao que se passava no restante da Europa. Como se lê no tratado de Bracton, citado acima, o fato de as leis inglesas serem diferentes, de serem mais costumeiras do que promulgadas, não as tornava menos leis, não as tornava contrárias ou contraditórias quanto ao direito natural ou ao direito das gentes. Olhada do ponto de vista histórico, não as tornava uma exceção ao desenvolvimento do Ocidente, embora se possa dizer que foi um 'acidente histórico' a Inglaterra ter escapado da onda de erudição que identificou os juristas medievais.

O fim da experiência medieval: humanismo jurídico

O ius commune sobreviveu, como já foi dito, até o final do século XVIII. Direito romano, direito canônico, costumes e legislação nacional acomodaram-se e conviveram dando vida a uma singular forma de cultura jurídica, comum à Europa ocidental e ao mundo ao qual se expandira, nomeadamente a América, com especial menção à América espanhola e portuguesa, no que nos interessa. Uma experiência forjada na Baixa Idade Média teve, portanto, longo fôlego, mesmo debaixo de críticas crescentes. A primeira e mais articulada delas apareceu com o humanismo jurídico em particular.

Nascido na Itália do século XV, o humanismo fez duas migrações de longo alcance. Em primeiro lugar a migração entre as disciplinas, os campos do saber: das humanidades em geral (história, ética, retórica) para o direito em particular. Depois, a migração geográfica, da Itália, seu berço, para a França e dali para o Norte da Europa, onde também viveram dois de seus mais importantes símbolos: Erasmo de Rotterdam (1466-1536), nascido na Holanda, mas cidadão do mundo, pois viajou e viveu em muitos lugares, e Thomas More (1478-1535), inglês universal no espírito, sem nunca ter se deslocado por toda parte como Erasmo.

A tradição humanista italiana reunia, no entanto, muita gente diversa e chega a ser difícil dizer que houve um humanismo só. Os humanistas definiram-se por alguns traços, que seriam também mais tarde o dos juristas humanistas. Um primeiro deles é seu estranhamento com relação à Idade Média. Por isso cunhariam a expressão renascimento, rinascitá, para indicar o que estava acontecendo com a cultura do seu tempo. O termo seria depois retomado por Giorgio Vasari (1511-1574), artista célebre por ter escrito a Vida dos Artistas (publicada em 1550), e por meio dele vulgarizado até chegar a nossos dias. 
Consideravam-se os intermediários privilegiados entre seu tempo e a Antiguidade clássica (BURCKHARDT, 1990, p. 135). Eram homens em busca da Antiguidade, tempo que imitavam sem poder restaurar. Delumeau (1984a, p. 19) lembra que nas suas cidades e repúblicas havia coisas que pertenciam totalmente a seu tempo, não à Antiguidade clássica: a imprensa, o relógio mecânico, a letra de câmbio, a contabilidade por partidas dobradas, os novos bancos, a nova agricultura. Foram eles que imaginaram os 900 anos que os separavam da Antiguidade como se fossem uma idade intermédia.

Não eram, porém, simples imitadores, restauradores ou tradicionalistas. Garin sugere, bem ao contrário, que a "filosofia humanista deu-se conta da ruptura que a Idade Média havia amadurecido e levado a extremos. (...) Em sua preocupação de definir-se através da definição do outro, na aquisição do sentido de história, que é o sentido do tempo, no perceber o tempo e a história como dimensões próprias da vida do homem, no liberar-se e destacar-se para sempre da imagem de um mundo sólido e fixo", o humanismo adquiriu uma característica que o opunha à Idade Média (GARIN, 2005, p. 99). Característica dos humanistas era, portanto, a consciência histórica e o amor à história.

Se essa é a situação do humanismo, e se o humanismo jurídico floresce a partir de final do quattrocento, que relação há entre humanismo e Idade Média? Seria apenas uma de exclusão, de contraste, de superação? Bem, apenas em parte. É que os humanistas realmente se opõem em termos de estilo e de método aos medievais. Mas é também verdade que se debruçam sobre alguns materiais comuns: a jurisprudência romana, o direito de base do ius commune. Mesmo na filosofia, conforme assinala o mesmo Garin, o primeiro humanismo voltava-se para Cícero como mestre de retórica, mas Aristóteles continuava a ser o mestre de moral (GARIN, 2001, p. 60). E também o mundo sobre o qual refletem é apenas em parte um mundo novo: da vida material muita coisa ainda sobrevive do mundo medieval, no que diz respeito, por exemplo, às formas de curar doenças, às fontes de energia, e às maneiras de se cultivar a terra. Ao mesmo tempo, muito já está em transformação. As guerras, para começar: luta-se na Itália, mas luta-se não mais a guerra civil das comunas ou a guerra contra o Imperador, mas um confronto entre os dois estados modernos em formação - França e Espanha. Luta-se como exércitos mercenários e não se lutam guerras dinásticas, mas guerras de Estados. O regime de servidão está praticamente abolido, vivendo o campo do trabalho de homens livres.

Além do estranhamento com a Idade Média, e da nova consciência histórica, de que falava Garin, os humanistas foram dedicados filólogos. Uma primeira e importante tradição humanista nesse sentido - deixando de lado a literatura propriamente dita e a extraordinária figura de Francesco Petrarca (1304-1374) - exemplifica-se com Lorenzo Valla (1406-1457) e Pico della Mirandola (1463-1494). Lorenzo Valla serviuse da filologia para destruir uma das maiores fraudes históricas forjadas pela Igreja, a 
Doação de Constantino. O documento circulava desde o século IX contendo uma doação de territórios feita por Constantino a Silvestre: seria o título a dar poderes temporais ao papa sobre imensas áreas da Itália, chamadas depois de Estados Pontifícios e sobre as quais exercia poderes senhoriais. Valla vê no texto construções pouco típicas do latim clássico. Da mesma maneira mostra como são usadas palavras desconhecidas do latim clássico, a sugerir que o ‘documento’ é uma fraude muito posterior. Indica também o uso de expressões anacrônicas aqui e ali. Um exemplo gritante, diz ele, é que o documento fala de Constantinopla e da condição de Constantinopla como uma das sés patriarcais. Ora, se o documento se dizia datado de três dias após a conversão - batismo de Constantino isso não poderia ser verdade, já que então Constantinopla ainda era Bizâncio e não era ainda sé patriarcal (visto que não tinha ainda o estatuto de Igreja da capital do império de fala grega)! Vê, finalmente, o anacronismo dos sentidos do texto: será que um Imperador de bom senso faria uma doação do centro de seu império, daquilo que lhe dava propriamente legitimidade? A doação forjada, diz Valla, faz justamente isto: Constantino doa não uma província, um trecho qualquer de seu Império, mas o seu próprio coração, Roma, e aquela parte que mais ricamente contribuiu para o próprio império, a Itália. Nada disso faria sentido: se por contrição ele quisesse fazer alguma coisa pelo seu reino, poderia ou ter restaurado a liberdade das cidades (e não simplesmente lhes dado um outro chefe, o papa), ou governado adequada e justamente. O trabalho de Valla é típico dessa atitude em primeiro lugar de desconfiança com relação ao poder eclesiástico e à tradição pura e simples, à superstição, como se dirá. É também típico na utilização da crítica textual como instrumento de reconstrução histórica. Valla, como humanista exemplar da crítica aos medievais, foi muitas vezes implacável. Deixou atrás de si não apenas a fama de humanista, mas um grupo de admiradores em toda parte. Seu trabalho criou, pois, uma escola cujos ecos foram sentidos também no campo do direito, como veremos a seguir no caso por tudo emblemático dos humanistas franceses, especialmente em Guilherme Budé (Budeus).

A crítica à superstição vai frequentemente dirigida à religião, ao culto aos santos, e sobretudo às relíquias. Nessa linha encontra-se o conhecido trabalho de Erasmo de Rotterdam (1466-1536), Elogio da Loucura (Encomium, id est, stultitiae laus, de 1509). Erasmo ironiza de várias maneiras o culto de seu tempo como nessa passagem:

Dizei-me se, entre tantos votos religiosos de reconhecimento que vedes cobrindo por completo as paredes e as abóbadas das igrejas, já vistes pendurado um único de reconhecimento por cura milagrosa da loucura. Decerto que não: os homens não costumam importunar os santos para obter graça dessa natureza. (...) Ora, bem vedes que ninguém deu graças a Deus, ou à Virgem, ou a qualquer outro santo, por ter recuperado o juízo. A loucura tem tantos atrativos para os homens, que, de todos os males, é ela o único que se estima 
como um bem. (ERASMO DE ROTTERDAM, 1972, p. 7576).

Não é demais lembrar que diversas práticas religiosas contemporâneas são acusadas por ele de não terem base ou fundamento, a não ser a exploração da boa-fé, ou mais propriamente a loucura (estupidez, estultícia - stultitia) dos seres humanos. O que não diz ele da venda das indulgências, estopim da Reforma desencadeada por Lutero? "Persuadidos dos perdões e das indulgências, ao negociante, ao militar, ao juiz, basta atirarem a uma bandeja uma pequena moeda, para ficarem tão limpos e tão puros dos seus numerosos roubos como quando saíram da pia batismal”. (ERASMO DE ROTTERDAM, 1972, p. 73).

Isto sem falar na crítica, também comum nos anos imediatamente anteriores à Reforma protestante, ao abandono em que se encontrava a atividade propriamente catequética e de cura d'almas:

Os papas, sempre ativos e incansáveis em sua tarefa de receber dinheiro, descarregam sobre os bispos tudo o que há de incômodo no apostolado; os bispos sobre os párocos; os párocos sobre os vigários; os vigários sobre os frades mendicantes; e os mendicantes, finalmente, enviam as ovelhas aos pastores espirituais, que sabem tosquiá-las e tirar-lhes proveito da lã. (ERASMO DE ROTTERDAM, 1972, p. 130).

Ou, finamente, ao ambiente de rivalidade entre os cristãos, muitas vezes apoiado pela própria Igreja, por clérigos, doutores e professores de filosofia, teologia ou direito (civil ou canônico):

Assim como a Igreja cristã foi fundada com sangue, confirmada com sangue, dilatada com sangue, assim também os papas a governam com sangue, como se nunca Jesus Cristo tivesse existido para protegê-la e sustentá-la. (....) Mas não faltam eruditos aduladores para dar a esse manifestíssimo delírio o nome de zelo, piedade e valor. E acham razões para provar que desembainhar a espada e cravá-la no coração de um irmão não é absolutamente infringir o grande mandamento da caridade para com o próximo. (ERASMO DE ROTTERDAM, 1972, p. 129).

A recepção de Aristóteles também foi objeto de polêmica entre os humanistas, o que significa algum desafio aos cultores do direito que haviam naturalizado o Filósofo. A escolástica havia dado grande importância ao procedimento analítico, à lógica da ciência, ou dos saberes, e ao estudo do corpus aristotélico referente a esses temas (os Tópicos, a Retórica, os Analíticos Primeiros e Segundos, sem falar na filosofia primeira, a Metafísica). Como diz Garin, Aristóteles não foi propriamente banido pelos 
humanistas, mas revisitado, traduzido novamente do grego e 'libertado' dos erros medievais e escolásticos (GARIN, 2001, p. 63 et seq.). Os humanistas retomaram ainda a filosofia moral ciceroniana (TUCK, 2001, p. 6-20; GARIN, 2001, p. 61). Propuseram-se então a rever as traduções feitas pelos medievais e constataram que eudemonia, na Ética de Aristóteles, correspondia a beatitudo, e não a felicitas como queriam os medievais; constataram que política era um barbarismo medieval, já que $\pi$ $\pi \circ \lambda \iota \sigma$ - a cidade - deveria traduzir-se por civilis, e que $\kappa \alpha \lambda o v$ deveria traduzir-se por honestum e não por bonum.

Os humanistas finalmente realizavam o grande movimento de retomada do platonismo na filosofia. Nesse contexto de luta das escolas - platônicos, ciceronianos e aristotélicos - Pico della Mirandola (1463-1494) propôs a busca de entendimento recíproco. Pico morreu muito jovem, aos 31 anos, justamente no dia em que Carlos VIII de França entrava em Florença. Foi, como Leon Battista Alberti (1404-1472), uma alma inquieta e extraordinariamente talentosa. Estudara hebraico, árabe, caldeu, e inclinavase ao platonismo. Em 1486, com 23 anos de idade, escreveu a célebre 'Oração sobre a dignidade do homem', para uma disputa que organizara em Roma sobre a paz filosófica (paz entre aristotelismo e platonismo). Seu ponto de partida, na abertura da famosíssima Oração, referia-se a uma expressão de um árabe: "Estimadíssimos pais (padres), li em um documento árabe que quando Abdala, o sarraceno, foi perguntado sobre o que neste mundo era mais digno de ser admirado, respondeu que nada era mais admirável do que o homem".

Essa concentração no ser humano pode ser vista como uma primeira e importante manifestação da modernidade, mas não deve ser levada a extremos. Em primeiro lugar, porque ainda não se tratava de conceber o ser humano à moda dos jusnaturalistas modernos da segunda metade do século XVII em diante. Em segundo lugar, porque tampouco se tratava de concebê-lo como membro de uma classe universal, algo que só se expandiu a partir do final do século XVIII. Finalmente, não se tratava de centralizar a vida moral e jurídica em torno da autonomia individual.

Além disso, é preciso não associar diretamente os humanistas e suas preocupações com nossa própria idade. Eles ainda diferem muito de nós, e inclinam-se a investigações que só podem dizer respeito a seu tempo: estudam astrologia e bruxaria, ocultismo e outras formas de relação com o futuro e a contingência, completamente estranhas ao pensamento científico e laico de hoje. Mesmo na jurisprudência, no estudo do direito, são essencialmente diferentes de nós e dos jusnaturalistas. Ainda estão inseridos em um estudo de fontes romanas e tomam como referência o corpo de direito romano, se bem que associado à crescente legislação nacional, muito especialmente no caso da França. 
A atenção ao texto e a crítica realizada por Lourenço Valla produziram efeitos sobre o direito. O primeiro caso mais relevante foi o de Guilherme Budé (14671540). Budé nascera de uma família burguesa, e estudara direito em Orleãs, isto é, na universidade mais próxima de Paris onde se poderia estudar direito romano. Aproximouse da corte de Carlos VIII, onde exerceu alguns cargos, e lá ficou tanto no reinado de Luís XII quanto no de Francisco I. Este, afinal e a instâncias de Budé, criou em 1530 um Colégio para professores que não se enquadravam nas linhas da Sorbonne, o Collège des lecteurs royaux, ou Collège de France, mais tarde chamado de Anti-Sorbonne. O comentário ao Digesto (Annotationes pandectarum libri, aqui citada na edição Veneziana de 1534) que produziu não deixava qualquer dúvida. Dedicou-se a uma crítica textual, de tal modo que Birocchi diz tratar-se de obra de um grammaticus (BIROCCHI, 1997, p. 105). Não se trata de grammaticus com um tom pejorativo, como costumavam os escolásticos dizer dos humanistas, mas no sentido próprio, visto que seu esforço é o de fazer com que se usem as palavras com clareza para pensar com sabedoria. De fato, depois de redigir um longo elogio a Lourenço Valla, pela sua perícia no latim, passava a criticar o trabalho dos juristas medievais, Acúrsio em primeiro lugar, mas também os franceses (ultramontanos), que não se davam conta das mudanças de sentido das palavras dos clássicos romanos para o seu tempo, nem mesmo se davam conta da possível confusão com os termos vulgares do francês que contaminavam a compreensão dos cognatos em latim e vice-versa (multa gallice dicim quae latine ignoramus, cfr. Budé (1534, 13 a). Sua crítica apoiava-se em longas citações de Aristóteles e Cícero. O último, como diz Birocchi, servia para sugerir uma mudança metodológica importante: "atualizava sua crítica à desordem do direito, cujos preceitos eram vaga \& sparsa, ac nulla certae artis ratione circunscripta" (BIROCCHI, 1997, p. 106).

O humanismo jurídico herdou o ius commune e o transformou. Seu impacto foi maior na Europa do Norte. Em Portugal sua repercussão foi pequena. Dos que se destacaram como humanistas, Henrique Caiado, Luis Álvares Nogueira, e Antonio Gouveia nunca retornaram a Portugal. Luís Teixeira, Diogo Mendes Vasconcelos e Miguel de Cabedo tiveram reduzida importância quando voltaram (COSTA, 1999, p. 325). Na França prosperou, com alguns dos mais importantes juristas filiando-se a essa escola: Andréa Alciato (1492-1550), vindo de Milão ensinou em Bruges entre 1529 e 1534 e deu início à tradição humanista em França; François Connan, Connanus (1508-1551), François Hotman (1524-1590), Hugo Doneau, o Donelus (1527-1591), Jacques Cujas, o Cujacius (1522-1590). Destes, o mais iconoclasta talvez tenha sido Hotman, cujo livro Anti Triboniano (1567) mostrava o quanto o Corpus Iuris Civilis estaria cheio de interpolações feitas pelos juristas de Justiniano, deturpando o direito romano clássico propriamente. Hotman levou uma vida atribulada, a despeito do reconhecimento generalizado de sua capacidade, porque se tornara um huguenote convicto (chegando a ser o secretário de 
Calvino) sempre disposto a polêmicas públicas, num tempo em que a profissão de uma fé religiosa era uma questão de morte.

Como se pode encerrar esta visão panorâmica da experiência jurídica medieval? Então se forjou boa parte da tradição de que somos herdeiros. A principal característica talvez seja justamente o desenvolvimento de uma disciplina que pretendia ser autônoma de outras, ainda que aparentadas, tais como a teologia e a filosofia moral. Essa autonomia, foi, porém, sempre relativa, pois que a sociedade medieval não se desvencilhou das hierarquias sociais e da inserção, ou talvez se deva dizer subordinação, dos indivíduos à ordem, ao todo que os precedia. Foi também relativa, pois eram patentes os limites dentro dos quais a discussão e o debate, que foram realmente acesos e vivos, poderiam dar-se. Entre esses limites contava-se uma ciência que não poderia formular hipóteses assumindo a inexistência de Deus. E visto que Deus era o fecho lógico de todo o sistema, e tinha, na visão comum dos medievais, uma representação na Terra (a Tradição, a Igreja, a comunidade dos fiéis, os bispos ou o papa) a existência dessa instância efetiva de poder - material e simbólico - era um obstáculo de vida ou morte para a expansão do pensamento. Com o humanismo e com a Reforma, ainda que sobrevivesse a necessidade de se presumir a existência de Deus (basta ler Hobbes ou Grócio para constatar isso ainda no século XVII), a diversidade das profissões cristãs apoiadas militarmente por diferentes poderes, passou a exigir formas de tolerância, das quais, aí sim, a noção contemporânea é legatária direta.

São Paulo, fevereiro de 2019.

\section{Referências}

ALONSO MARTIN, M. L. La dote en el derecho local y en el derecho territorial castellano bajo la recepción. In: Diritto comune i diritti locali nella storia dell'Europa: atti del Convengo di Varenna (12-15 giungo 1979): sotto il patrocinio dell'instituto lombardo e della Regione Lombardia. Milano: Giuffrè, 1980.

BAKER, John Hamilton. The common law tradition: lawyers, books, and the law. Londres: Hambledon Press, 2000.

BELLOMO, Manlio. Società e istituzioni dal medioevo agli inizi dell'età moderna. Roma: Il Cigno Galileo Galilei, 1994.

. The common legal past of Europe, 1000-1800. Translated by Lydia G. Cochrane. Washington, D.C.: Catholic University of America Press, 1995.

BERMAN, Harold J. Law and revolution: the formation of the Western legal tradition. Cambridge, MA: Harvard University Press, 1983. 
BIROCCHI, Italo. Alla ricerca dell'ordine: fonti e cultura giuridica nell'età moderna. Torino: Giappichelli, 2002.

Causa e categoria generale del contratto: un problema dogmatico nella cultura privatistica dell'età moderna. Torino: Giappichelli, 1997.

BLACK, Antony. Political thought in Europe, 1250-1450. Cambridge: Cambridge University Press, 1993.

BLOCH, Marc. Introducción a la historia. Traducción de Pablo González Casanova y Max Aub. México, D.F.: Fondo de Cultura Económica, 1990.

BOEHNER, Philotheus; GILSON, Étienne. História da filosofia cristã: desde as origens até Nicolau de Cusa. Tradução de Raimundo Vier. Petrópolis: Vozes, 1991.

BRUNDAGE, James A. Medieval canon law. London: Longman, 1995.

. The medieval origins of the legal profession: Canonists, Civilians, and Courts. Chicago: Chicago University Press, 2008.

BRUNNER, Otto. Neue wege der sozialgeschichte. Göttingen: Vandenhoeck \& Ruprecht, 1956.

. Sozialgeschichte Europas im Mittelalter. Göttingen: Vandenhoek \& Ruprecht, 1978.

BURCKHARDT, Jacob. The civilization of the renaissance in Italy. Translated by S. G. C. Middlemore with a new introduction by Peter Burke and notes by Peter Murray. London: Penguin Books, 1990.

BURKE, Peter. Montaigne. Madri: Alianza Editorial, 1985.

CAENEGEM, Raoul Charles van. I signori del diritto: legislatori e professori nella storia europea. Milano: Giuffrè, 1991.

. Juízes, legisladores, e professores. Tradução Luís Carlos Borges. Rio de Janeiro: Elsevier, 2010.

. The birth of the English common law. 2. ed. Cambridge: Cambridge University Press, 1989.

CAETANO, Marcelo Jose das Neves Alves. História do direito português: fontes direito público: (1140-1495). 3. ed. Lisboa: Verbo, 1992.

CALASSO, Francesco. I glossatori e la teoria della sovranità: studio di diritto comune pubblico. Milano: Giuffrè, 1957.

. Il negozio giuridico: lezioni di storia del diritto italiano. 2. ed. Milano: Giuffrè, 1959. . Medio Evo del diritto. Milano: Giuffrè, 1954. v. 1: Le fonti.

CANNING, Joseph. A history of medieval political thought. London: Routledge, 1996. 
CANNING, Joseph. The political thought of Baldus de Ubaldis. Cambridge: Cambridge University Press, 2003.

CHARLE, Christophe; VERGER, Jacques. História das universidades. São Paulo: UNESP, 1996.

CORTESE, Ennio. Il diritto nella storia medievale. Roma: Il Cigno Galileo Galilei, 1999. v. 2.

. La norma giuridica: spunti teorici nel diritto comune classico. Milano: Giuffrè, 1962. v. 1. . La norma giuridica: spunti teorici nel diritto comune classico. Milano: Giuffrè, 1964. v. 2.

COSTA, Mário Júlio de Almeida. História do direito português. Coimbra: Almedina, 1999.

DELUMEAU, Jean. A civilização do renascimento. Lisboa: Editorial Estampa, 1984a. v. 1. . A civilização do renascimento. Lisboa: Editorial Estampa, 1984b. v. 2.

FERNÁNDEZ-SANTAMARÍA, José Antonio. The state, war and peace: Spanish political thought in the renaissance 1516-1559. London: Cambridge University Press, 1977.

GARCÍA Y GARCÍA, Antonio. As faculdades de direito. In: RIDDER-SYMOENS, Hilde de. (coord.). Uma história da universidade na Europa. Lisboa: Imprensa Nacional - Casa da Moeda, 1996. v. 1: as universidades na Idade Média.

GARIN, Eugenio. La cultura filosofica del rinascimento italiano: ricerche e documenti. Milano: Bompiani, 2001. . Medioevo e rinascimento: studi e ricerche. Rome: Laterza, 2005.

GILISSEN, John. Introdução histórica ao direito. Tradução de A. M. Hespanha e L. M. Macaísta Malheiros. Lisboa: Fundação Calouste Gulbenkian, 1988.

GILSON, Étienne. A filosofia na Idade Média. São Paulo: Martins Fontes, 1995. . The spirit of medieval philosophy. London: Notre Dame University Press, 1991.

GORDLEY, James. The philosophical origins of modern contract doctrine. Oxford: Clarendon Press, 1991.

GROSSI, Paolo. "Dominia" e "servitudes": invenzioni sistematiche del diritto comune in tema di servitù. Milano: Giufrrè, 1989. p. 331-394. (Quaderni fiorentini per la storia del pensiero giuridico moderno, 18).

Gradus in dominio: Zasius e la teorica del dominio diviso. Milano: Giufrrè, 1985. p. 373399. (Quaderni fiorentini per la storia del pensiero giuridico moderno, 14).

. Ideologia e tecnica in una definizione giuridica: la definizione obertina di Feudo dai Glossatori a Cujas. Milano: Giufrrè, 1990. p. 179-208. (Quaderni fiorentini per la storia del pensierio giuridico moderno, 19). 
GROSSI, Paolo. Il diritto tra norma e applicazione. Firenze: Facoltá di giurisprudenza, 2002. (Aula inaugural na Escola de especialização para profissões jurídicas).

. L'ordine giuridico medievale. Roma: Laterza, 1995.

. La proprietà e le proprietà nell'officina dello storico. Milano: Giufrrè, 1988. p. 359-422.

(Quaderini fiorentini per la storia del pensiero giuridico moderno, 17).

. Le situazioni reali nell'esperienza giuridica medievale. Padova: Cedam, 1968.

. Proprietà in generale: diritto intermedio. In: Enciclopedia del diritto, Milano, v. 37, p. 225-254, 1988a.

HASKINS, Charles H. The renaissance of the twelfth century. Cambridge, MA: Harvard University Press, 1995.

HELMHOLZ, R. H. The spirit of classical canon law. Athens, GA: University of Georgia Press, 1996.

HESPANHA, António Manuel. História das instituições: épocas medieval e moderna. Coimbra: Livraria Almedina, 1982.

HUIZINGA, Johan. L'automne du Moyen Age. Paris: Payot et Rivage, 2002.

LANGE, Hermann. Römisches recht im mittelalter. Munique: C. H. Beck, 1997. v. 1: die glossatoren.

LARIVAILLE, Paul. A Itália no tempo de Maquiavel: Florença e Roma. Tradução Jônatas Batista Neto. São Paulo: Companhia das Letras, 1988.

LE GOFF, Jacques. Os intelectuais na Idade Média. Rio de Janeiro: José Olympio, 2003.

LECLER, Joseph. Histoire de la toleránce au siècle de la réforme. Paris: Albin Michel, 1994.

LOPES, José Reinaldo de Lima. As palavras e a lei: direito, ordem e justiça na história do pensamento jurídico moderno. São Paulo: Editora 34, 2004.

LOPES, José Reinaldo de Lima. O direito na história: lições introdutórias. São Paulo: Max Limonad, 2000.

MAFFEI, Domenico. Gli inizi dell'umanesimo giuridico. Milano: Giuffrè, 1964.

MAITLAND, Frederic William. The constitutional history of England: a course of lectures delivered. Cambridge: Cambridge University Press, 1965.

MARTÍNEZ DÍEZ, Gonzalo. Los comienzos de la recepción del derecho romano en España y el Fuero Real. In: Diritto comune e diritti locali nella storia dell'Europa: atti del Convengo di Varenna (12-15 giungo 1979): sotto il patrocinio dell'instituto lombardo e della Regione Lombardia. Milano: Giuffrè, 1980. 
MOHNHAUPT, Heinz. Privatrecht in privilegien. In: VORTRÄGE ZUR GESCHICHTE DES PRIVATRECHTS IN EUROPA, 9.-12., 1981, Frankfurt am Main. Anais [...]. Frankfurt am Main: Klostermann, 1981. p. 58-75. (Ius commune: Veröffentlichungen des Max-Planck-Instituts für Europäische Rechtsgeschichte. Sonderhefte: Texte und Monographien 15).

MORAW, Peter. Carreiras profissionais dos diplomados pelas universidades. In: RIDDERSYMOENS, Hilde de. (coord.). Uma história da universidade na Europa. Lisboa: Imprensa Nacional - Casa da Moeda, 1996. v. 1: as universidades na Idade Média.

MUSSELLI, Luciano. Storia del diritto canônico: introduzione alla storia del diritto e delle istituzioni ecclesiali. Torino: Giappichelli, 1992.

NASCIMENTO, Carlos Arthur Ribeiro do. De Tomás de Aquino a Galileu. Campinas: Unicamp, 1995.

. O que é filosofia medieval. São Paulo: Brasilense, 1992.

. Santo Tomás de Aquino: o boi mudo da Sicília. São Paulo: EDUC, 1992a.

OSLER, Douglas J. Legal humanism, 2004. Disponível em: http://www.mpier.uni-frankfurt.de/ forschung/mitarbeiter_forschung/osler-legal-humanism. Acesso em: 6 set. 2004.

PADOA-SCHIOPPA, Antonio. Italia ed Europa nella storia del diritto. Bolonha: Il Mulino, 2003.

PAGDEN, Anthony. (ed.). Spanish imperialism and the political imagination: studies in European and Spanish-American social and political theory 1513-1830. London New Haven: Yale University Press, 1990.

. The languages of political theory in early-modern Europe. Cambridge: Cambridge University Press, 1987.

PENNINGTON, Kenneth. The prince and the law, 1200-1600: sovereignty and rights in the western legal tradition. Berkeley, CA: University of California Press, 1993.

PIANO MORTARI, Vincenzo. Cinquecento giuridico francese: lineamenti generali. Napoli: Liguori, 1990.

. Dogmatica e interpretazione: i giuristi medievali. Napoli: Jovene, 1976.

. Interpretazione (diritto intermedio). In: ENCICLOPEDIA del Diritto. Milano: Giuffrè, 1972. v. 22 .

. Itinera juris: studi di storia giuridica dell'età moderna. Napoli: Jovene, 1991.

. 'Studia humanitatis' e 'Scientia iuris'. In: BUDÉ, Guillaume. Studia Gratiana. Bononiae: Institutum Iuridicum Universitatis Studiorum Bononiensis, 1967. v. 14, p. 437-458. (Col. Stephan Kuttner, 4).

POCOCK, John Greville Agard. The Machiavellian moment: Florentine political thought and the Atlantic republican tradition. Princeton, N.J.: Princeton University Press, 1975. 
QUAGLIONI, Diego. La giustizia nel medioevo e nella prima età moderna. Bolonha: Il Mulino, 2004.

. La sovranità. Roma-Bari: Laterza, 2004a.

. Politica e diritto nel Trecento italiano: il 'De Tyranno" di Bartolo da Sassoferrato (13141357). Firenze: Leo S. Olschki, 1983.

RIBEIRO, Renato Janine. Lorenzo Valla e os inícios da análise de texto. In: A última razão dos reis: ensaios sobre filosofia e política. São Paulo: Companhia das Letras, 1993.

RIDDER-SYMOENS, Hilde de. (coord.). Uma história da universidade na Europa. Lisboa: Imprensa Nacional - Casa da Moeda, 1996. v. 1: as universidades na Idade Média.

RILEY, Lawrence J. The history, nature and use of epikeia in moral theology. Delia, KS: Saint Pius X Press, 2012.

ROMANO, Ruggiero; e TENENTI, Alberto. Los fundamentos del mundo moderno. México: Siglo Veintiuno Ed., 1977.

ROSSI, Giovanni. Dottrine giuridiche per un mondo complesso: autonomia di ordinamenti e poteri pazionati in un "consilium" inedito di Tiberio Deciani per la comunitá di Fiemme. In: SBRICCOLI, Mario et al. Ordo iuris: storia e forme dell'esperienza giuridica. Milano: Giuffrè, 2003.

RYAN, Magnus. Bartolus of Sassoferrato and free cities. Transactions of the Royal Historical Society, Cambridge, v. 10, p. 65-89, Dec. 2000.

SÁNCHEZ-ARCILLA BERNAL, José. Estudio introductorio. In: ALPHONSE X, roi de Castille et de León. Las siete partidas: el libro del Fuero de las Leyes. Madrid: Reus, 2004.

SANTINI, Giovanni. Materiali per la storia del diritto comune in Europa. Torino: Giappichelli, 1990. v. 1: Lo "ius commune" nel pensiero giuridico: una struttura di lunga durata.

SAVIGNY, Friedrich Karl von. Storia del diritto romano nel medio evo. Trad. Emmanuele Bollati. Turim: Gianini e Fiore, 1854. v. 1.

SCHIAVONE, Aldo. Ius: l'invenzione del diritto in Occidente. Torino: Giulio Einaudi Ed., 2005.

SCHMOECKEL, Mathias. Liberty of conscience and the right of resistance in Montaigne's essays and Charron's 'La Sagesse', 2004. Disponível em: https://forhistiur.de/media/ zeitschrift/0205schmoeckel.pdf.

TIERNEY, Brian. Foundations of the conciliar theory: the contribution of the medieval canonists from Gratian to the Great Schism. London: Cambridge University Press, 1968.

. The crisis of church and state, 1050-1300. Englewood Cliffs, NJ: Prentice-Hall, Inc., 1964.

. The idea of natural rights: studies on natural rights, natural law, and church law 1150-1625.

Grand Rapids, MI: William. B. Eerdmans Publ., 1997. 
TIERNEY, Brian. "The prince is not bound by the laws": accursio and the origins of the modern state. Comparative Studies in Society and History, Cambridge, v. 5, n. 4, p. 378-400, July 1963.

TOCQUEVILLE, Alexis de. Democracy in America. New York: Harper Perennial, 1988.

TUCK, Richard. Natural rights theories: their origins and development. Cambridge: Cambridge University Press, 1998.

. Philosophy and government, 1572-1651. Cambridge: Cambridge University Press, 1993.

The rights of war and peace: political thought and the international order from Grotius to Kant. Oxford: Oxford University Press, 1999.

ULLMANN, Walter. A history of political thought: the middle ages. Harmondsworth, UK: Penguin Books, 1968.

. The medieval idea of law, as represented by Lucas de Penna: a study in fourteenth-century legal scholarship. London: Methuen \& Co. Ltd., 1946.

VERGER, Jacques. Homens e saber na idade média. Bauru: Edusc, 1999.

VILLATA, Gigliola di Renzo. Diritto comune e diritto locale nella cultura giuridica lombarda dell'età moderna. In: Diritto comune i diritti locali nella storia dell'Europa: atti del Convengo di Varenna (12-15 giungo 1979): sotto il patrocinio dell'instituto lombardo e della Regione Lombardia. Milano: Giuffrè, 1980.

VOLANTE, Raffaele. Fatto normativo e interpretatio iuris: la definizione del possesso nel diritto comune. In: SBRICCOLI, Mario et al. Ordo iuris: storia e forme dell'esperienza giuridica. Milano: Giuffrè, 2003.

. Il sistema contrattuale del diritto comune classico: struttura dei patti e individuazione del tipo: glossatori e ultramontani. Milano: Giuffrè, 2001.

Obras de referência e seleção de fontes

GEARY, Patrick J. (ed.). Readings in medieval history. Lewiston, NY: Broadview Press, 1991.

LOYN, Henry R. (org.). Dicionário da idade média. Rio de Janeiro: Jorge Zahar, 1992.

STOLLEIS, M. (org.) Juristen: ein biographisches Lexicon von der antike bis zum 20. München: C. H. Beck, 1995.

TIERNEY, Brian. The middle ages: sources of medieval history. 2. ed. New York: Alfred A. Knopf Ed., 1973. v. 1. 


\section{Fontes impressas}

ABELARDO, Pedro. Lógica para principiantes. Trad. Carlos Arthur Ribeiro Nascimento. Petrópolis: Vozes, 1994.

AZO, Portius. Sũma Azonis sup[er] libros Codicem sũma eiusdem sup[er] Institutiones. Speyer: Peter Drach, 1482.

BARTOLUS de Sassoferrato. Consilia, questiones et tractatus Bartoli: cum additionibus novis. Mediolani: Jacomo e fratelil De Legnano, 1506.

. Super institutionibus iuris civilis commentaria. Lugduni: Sebastianum de Honoratis, 1559.

BRACTON, Henry de. De legibus et consuetudinibus angliae. Translated by George E. Woodbine with revisions and notes by Samuel E. Thorne. Cambridge, MA: Harvard University Press, 1968.

BUDÉ, Guillaume. Annotationes in pandectarum libris. Venetii: Lodoco Badis Ascensio, 1534.

DONELLUS, Hugo. Commentariorum de iure civili libri viginti octo. Francoforte: Andrea Wecheli heredes, 1596.

. Commentarium iuris civilis libri viginti octo. Francoforte: Danielem \& Davidem Aubrios \& Clementem Schleichium, 1626.

. Opera omnia. Roma: Josephi Salviucci, 1828.

ERASMO DE ROTTERDAM. Elogio da loucura: a utopia. Tradução e notas de Paulo M. Oliveira. São Paulo: Abril Cultural, 1972.

GLANVILLE, Ranulf de. The treatise on the laws and customs of the realm of England commonly called Glanvill. Edited and translated by George Derek Gordon Hall. Oxford: Oxford University Press, 1990.

GRACIANO. Decretum (cum glosa). Strasbourg: Johannis Reinhold Grininger, 1490.

. The treatise on laws (Decretum DD. 1-20). Translated by Augustine Thompson, O.P. with the Ordinary Gloss translated by James Gordley and an introduction by Katherine Christensen. Washington, DC: The Catholic University of America, 1993.

UBALDI, Baldo degli. Lectura super Digesto Novo. Veneza: Andreas Torreanus, 1495. 